\title{
Gap Junctional Coupling and Patterns of Connexin Expression among Neonatal Rat Lumbar Spinal Motor Neurons
}

\author{
Qiang Chang,, ${ }^{1}$ Michael Gonzalez, ${ }^{1}$ Martin J. Pinter, ${ }^{2}$ and Rita J. Balice-Gordon ${ }^{1}$ \\ ${ }^{1}$ Department of Neuroscience, University of Pennsylvania School of Medicine, Philadelphia, Pennsylvania 19104-6074, \\ and ${ }^{2}$ Department of Physiology, Emory University School of Medicine, Atlanta, Georgia 30322
}

Interneuronal gap junctional coupling is a hallmark of neural development whose functional significance is poorly understood. We have characterized the extent of electrical coupling and dye coupling and patterns of gap junction protein expression in lumbar spinal motor neurons of neonatal rats. Intracellular recordings showed that neonatal motor neurons are transiently electrically coupled and that electrical coupling is reversibly abolished by halothane, a gap junction blocker. Iontophoretic injection of Neurobiotin, a low molecular weight compound that passes across most gap junctions, into single motor neurons resulted in clusters of many labeled motor neurons at postnatal day 0 (P0)-P2, and single labeled motor neurons after P7. The compact distribution of dye-labeled motor neurons suggested that, after birth, gap junctional coupling is spatially restricted. RT-PCR, in situ hybridization, and immu- nostaining showed that motor neurons express five connexins, Cx36, Cx37, Cx40, Cx43, and Cx45, a repertoire distinct from that expressed by other neurons or glia. Although all five connexins are widely expressed among motor neurons in embryonic and neonatal life, $\mathrm{Cx} 36, \mathrm{C} \times 37$, and $\mathrm{Cx} 43$ continue to be expressed in many adult motor neurons, and expression of Cx45, and in particular Cx40, decreases after birth. The disappearance of electrical and dye coupling despite the persistent expression of several gap junction proteins suggests that gap junctional communication among motor neurons may be modulated by mechanisms that affect gap junction assembly, permeability, or open state.

Key words: gap junction; motor neuron; connexin; spinal cord; neuromuscular junction; activity
Gap junctional coupling is widespread throughout the developing mammalian nervous system, among neurons as well as among glia (for review, see Dermietzel and Spray, 1993; Kandler and Katz, 1995). Roles for gap junctional communication in mediating pattern formation, cell migration, neuronal differentiation, and circuit formation have been proposed (Connors et al., 1983; Yuste et al., 1992; Peinado et al., 1993; Kandler and Katz, 1995; Bittman et al., 1997; Rozental et al., 1998; Nadarajah and Parnavelas, 1999). Although pharmacological or genetic disruption of gap junctional coupling leads to developmental abnormalities in many tissues (for review, see Nicholson and Bruzzone, 1997), the functional significance of gap junctional communication during neural development is largely unknown. In contrast, in the adult mammalian nervous system, neuronal gap junctional coupling seems to be restricted (Llinas, 1985) primarily to groups of neurons in which temporal correlations among activity are important for function. Among inferior olive neurons (Llinas and Sasaki, 1989), hippocampal pyramidal neurons (MacVicar and Dudek, 1981), abducens motor neurons (Gogan et al., 1974), and neurons in the mesencephalic nucleus of the trigeminal nerve (Baker and Llinas, 1971), gap junctions rapidly transmit electrical potentials from

\footnotetext{
Received Aug. 16, 1999; revised Sept. 23, 1999; accepted Sept. 28, 1999.

This work was supported by grants from National Institutes of Health (NS34373), the Spinal Cord Research Foundation (1472), and the McKnight Foundation to R.B.-G. We thank Drs. R. Kalb and H. Fryer for help with motor neuron purification; Drs. L. Bone, E. Hertzberg, M. Koval, C. Lo, B. Nicholson, D. Paul, and S. Scherer for generously providing connexin-specific PCR primers, cDNAs, antibodies, and/or mutant mice; and Drs. D. Kopp, A. Pereda, and K. Personius for helpful discussions and comments on earlier versions of this manuscript.

Correspondence should be addressed to Rita Balice-Gordon, Department of Neuroscience, University of Pennsylvania School of Medicine, 215 Stemmler Hall, Philadelphia, PA 19104-6074. E-mail: rbaliceg@mail.med.upenn.edu.

Copyright (C) 1999 Society for Neuroscience 0270-6474/99/1910813-16\$05.00/0
}

one cell to another, thus shaping temporal relationships in the firing patterns among ensembles of neurons.

We are particularly interested in understanding the mechanisms that shape motor neuron firing during the perinatal period, when activity-dependent synaptic competition sculpts the innervation of individual muscle fibers from several inputs to a single input (for review, see Thompson, 1985; Nguyen and Lichtman, 1996). Gap junctional coupling is one of several mechanisms that might bias motor neuron activity to be temporally similar, and this may play a role in the establishment and maintenance of multiple innervation of muscle fibers. Relatively synchronous activity among several inputs to muscle fibers may prevent or slow synaptic competition. The disappearance of gap junctional coupling may result in motor neuron activity becoming less synchronous, driving competition (Balice-Gordon and Lichtman, 1994). Adult mammalian motor neurons are not generally electrically coupled or dye coupled, but electrical potentials have been reported in rat lumbar spinal motor neurons around the time of birth (Fulton et al., 1980; Walton and Navarette, 1991), although these have not been well documented. Thus it was of interest to determine the temporal and spatial extent of electrical compared with dye coupling. We also determined the repertoire and pattern of gap junction protein expression among motor neurons during perinatal life. We reasoned that a comparison of the spatial and temporal patterns of gap junctional coupling with connexin expression would provide insight into how motor neuron intercellular communication might be modulated during development. Understanding which gap junction proteins are developmentally regulated in motor neurons would also help determine which mutant animals and other manipulations would be informative for asking functional questions in future work. 
Using intracellular recordings from identified motor neurons in neonatal rat lumbar spinal cord and iontophoretic injection of Neurobiotin, a low molecular weight compound that passes across gap junctions, into single identified motor neurons, we found that the percentage of dye and electrically coupled motor neurons declines rapidly in the first week after birth. The compact distribution of dye-labeled motor neurons within a cluster suggested that, at the postnatal ages examined, coupling is spatially restricted. We also found that the repertoire and pattern of motor neuronal gap junction protein (connexin) expression is unique compared with those previously reported for other neurons and glia (for review, see Dermietzel and Spray, 1993; Nadarajah and Parnavelas, 1999). Cx36, Cx37, Cx40, Cx43, and Cx45 are relatively uniformly expressed across motor columns throughout embryonic development, but after birth, the number of motor neurons that express $\mathrm{Cx} 45$ and in particular $\mathrm{Cx} 40$ declines. Despite the disappearance of gap junctional coupling among motor neurons by the end of the first week after birth, connexin mRNA and protein continue to be expressed in many adult motor neurons. Taken together, these results suggest that gap junctional coupling among motor neurons is developmentally regulated, and that adult motor neurons continue to express several gap junction proteins despite the absence of functional gap junctions.

Preliminary reports of this work have been published previously in abstract form (Chang and Balice-Gordon, 1997; Chang et al., 1998).

\section{MATERIALS AND METHODS}

Animals and spinal cord preparation. Timed pregnant female Sprague Dawley rats were purchased from Charles River. The day of birth was designated postnatal day $0(\mathrm{P} 0)$. P0-P7 rats were anesthetized on ice and decapitated; P8-P10 rats were injected intraperitoneally with an overdose of sodium pentobarbital and decapitated. The lumbar spinal cord was quickly exposed via a dorsal laminectomy and superfused with cold Ringer's solution containing (in $\mathrm{mm}$ ): $116 \mathrm{NaCl}, 5 \mathrm{KCl}, 4 \mathrm{CaCl}_{2}, 1$ $\mathrm{MgSO}_{4}, 29 \mathrm{NaHCO}_{3}, 1 \mathrm{NaH}_{2} \mathrm{PO}_{4}$, and 11 glucose, bubbled with $95 \%$ $\mathrm{O}_{2} / 5 \% \mathrm{CO}_{2}$. The meninges were carefully removed, and the cord was hemisected as described previously (Ziskind-Conhaim, 1988). One or both halves of the spinal cord, with dorsal and ventral roots intact, were transferred to a recording chamber superfused with oxygenated Ringer's solution at room temperature $\left(25^{\circ} \mathrm{C}\right)$.

Intracellular recording from identified motor neurons. The L3, L4, and/or L5 ventral roots were placed in suction electrodes so that $\sim 3 \mathrm{~mm}$ of root was left between the tip of the suction electrode and the spinal cord surface. Roots were stimulated at $1 \mathrm{~Hz}$ with square pulses of $100-200 \mu \mathrm{V}$ and 100-200 $\mu \mathrm{sec}$ duration. Using sharp high-resistance microelectrodes (80-120 M $\Omega$ ) filled with a solution of $4 \%$ Neurobiotin (Vector Laboratories, Burlingame, CA) dissolved in $2 \mathrm{M} \mathrm{KCl}$ and $10 \mathrm{~mm}$ HEPES buffer, motor neuron location was determined by locating extracellular field potentials (Fulton et al., 1980). Impaled neurons were identified as motor neurons by the presence of an antidromic action potential after ventral root stimulation. Cells with resting potentials of $-60 \mathrm{mV}$ or more hyperpolarized and action potentials of $60 \mathrm{mV}$ or higher were characterized further. Data were acquired digitally, stored onto a PC, and analyzed off-line. In most cases, particularly at P3-P4, coupling potentials were measured from averaged records (10-20 sweeps) after subtraction of averaged extracellular antidromic field potential records.

Pharmacological blockade of gap junctions. In some experiments, a gap junction blocker, halothane (Sigma, St. Louis, MO) (Burt and Spray, 1989; Peinado et al., 1993), was used to determine whether coupling potentials could be reversibly attenuated or abolished. After motor neurons were identified as described above and coupling potentials were characterized, halothane-saturated oxygenated Ringer's solution was perfused over the spinal cord for several minutes while continuous recordings were made. Halothane-saturated Ringer's solution was then washed out, and recovery was monitored.

Neurobiotin injection and histology. In some experiments, Neurobiotin was iontophoretically injected $(0.5-4.0 \mathrm{nA}, 400 \mathrm{msec}, 1 \mathrm{~Hz}, 10-20 \mathrm{~min})$ into single, identified motor neurons. To determine whether dye leakage into the extracellular space could spuriously result in the labeling of multiple motor neurons, in some experiments, Neurobiotin was iontophoretically deposited extracellularly (1-5 nA, $400 \mathrm{msec}, 1 \mathrm{~Hz}, 10-20 \mathrm{~min})$.

After a period of at least $2 \mathrm{hr}$ to allow Neurobiotin to diffuse across putative gap junctions, the spinal cords were fixed in $4 \%$ paraformaldehyde for $4 \mathrm{hr}$ at room temperature, washed extensively in PBS, cryoprotected in $20 \%$ sucrose/PBS at $4^{\circ} \mathrm{C}$ overnight, embedded in OCT (Sakura), and frozen in an acetone/dry-ice bath. Serial parasagittal sections of spinal cords were cut at $25-35 \mu \mathrm{m}$ on a cryostat (Leica CM3000) and collected onto slides. Sections were permeablized in methanol at $-20^{\circ} \mathrm{C}$ for $3 \mathrm{~min}$, blocked in a solution of $2 \%$ BSA, $0.1 \%$ Triton $\mathrm{X}-100$, PBS at room temperature for $1 \mathrm{hr}$, stained with $50 \mu \mathrm{g} / \mathrm{ml}$ FITCconjugated streptavidin in block at $4^{\circ} \mathrm{C}$ overnight, rinsed in PBS, mounted in VectaShield (Vector Laboratories), and coverslipped. Sections were examined using confocal microscopy (Leica TCS 4D system). The diameter and location of labeled motor neurons were determined from image reconstructions of spinal cord sections using interactive software (MetaMorph, Universal Imaging, West Chester, PA).

Motor neuron culture. Motor neurons were isolated from embryonic day 15 (E15) rat spinal cord as previously described (Camu and Henderson, 1992, 1994). This purification consists of ventral horn dissection, a metrizamide density gradient centrifugation to enrich for large cells, and immunopanning using an antibody (mAb 192; Developmental Studies Hybridoma Bank) against the low-affinity nerve growth factor receptor (NGFR), resulting in isolation of large-diameter, NGFR-expressing cells from the ventral spinal cord. It was not possible to purify motor neurons from postnatal animals (Camu and Henderson, 1992, 1994). The cellular composition of cultures was determined by immunostaining with an antibody against an early motor neuron marker, Islet-1 (4D5, Developmental Studies Hybridoma Bank) (Tsuchida et al., 1994). Although 4D5 also stains interneurons, their relatively dorsal position and small size make it unlikely to be present after purification (Camu and Henderson, 1992, 1994). Twenty-four to forty-eight hours after being placed into culture, motor neurons were harvested, and total RNA was prepared for RT-PCR analysis of connexin expression.

RT-PCR analysis of connexin expression. Total RNA was extracted from purified E15 rat motor neurons or from E15 or P1 ventral spinal cord using TRIzol (Life Technologies, Gaithersburg, MD) and then treated with RNase-free DNase to remove genomic DNA. Total RNA (1 $\mu \mathrm{g})$ was reverse-transcribed into first-strand cDNA, using Advantage RT-for-PCR kit (Clontech, Cambridge, UK). Primers were designed for Cx26, Cx30, Cx31, Cx31.1, Cx32, Cx33, Cx36, Cx37, Cx40, Cx43, Cx45, $\mathrm{Cx} 46$, and $\mathrm{Cx} 50$ to amplify a unique coding region of each gene. The primer sequences for each connexin were as follows: Cx26 5'CGGAAGTTCATGAAGGGAGAGAT, Cx263'-GGTCTTTTGGACT TCCCTGAGCA; Cx30.3 5'-ATGAACTGGGGATTTCTCCAG, Cx30.3 3'-TCATGGATACACACCTGCATC; Cx31 5'-ATGGATTGGAAGAA GCTTCAG, Cx313'-TTAAATGGGGGTCAGGCTAGG;Cx325'-CTGC TCTACCCGGGCTATGC, Cx32 3'-CAGGCTGAGCATCGGTCGCTT TC; Cx33 5'-GCCAGTGGGGAAAGGCGCTTGCA, Cx33 3'-CCCAC CGGGACTACCTGATC; Cx37 5'-GGCTGGACCATGGAGCCGGT, Cx37 3'-TTCTGGCCACCCTGGGGGGC; Cx40 5'-CTGGCCAAGTC ACGGCAGGG, Cx40 3'-TTGTCACTGTGGTAGCCCTGAGG; Cx43 5'-TACCACGCCACCACTGGCCCA, Cx43 3'-ATTCTGGTTGTCGTC GGGGAAATC; Cx45 5'-GGGCAAACCAATTCCACCACC, Cx45 3'CAAGATTAAATCCAGACGGAG; Cx46 5'-GGAAAGGCCACAGG GTTTCCTGG, Cx46 3'-GGGTCCAGGAGGACCAACGG; Cx50 5'-CC TTTGACAGAGGTTGGAATCGTG, Cx50 3'-CCGATTGTCATCGGT TGTCAGCTC. Primers designed to recognize mouse Cx36 as described in Condorelli et al. (1998) were also synthesized.

The $25 \mu \mathrm{l} \mathrm{PCR}$ mixture contained 5-10 $\mu \mathrm{l}$ first-strand cDNA, $0.8 \mu \mathrm{M}$ deoxynucleotide triphosphates, $100 \mathrm{ng}$ of each primer, $3.5 \mu \mathrm{M}$ magnesium, $2.5 \mu \mathrm{l} 10 \times$ PCR buffer (Life Technologies), and 1.25 U Taq polymerase (Life Technologies). The PCR conditions were $94^{\circ} \mathrm{C}$ for 5 min, $94^{\circ} \mathrm{C}$ for $45 \mathrm{sec}, 55^{\circ} \mathrm{C}$ for $30 \mathrm{sec}$, and $72^{\circ} \mathrm{C}$ for $1 \mathrm{~min}$ for 35 cycles followed by $72^{\circ} \mathrm{C}$ for $10 \mathrm{~min}$. In each case, total RNA was used as a negative control template, and cDNA from tissues known to express a particular connexin(s), such as heart, skin, eye, liver, and testis, were used as positive control templates for the PCR reactions. RT-PCR products from spinal cord, purified embryonic motor neurons, and/or positive control tissues were analyzed using gel electrophoresis. All products were sequenced and compared with sequences in GenBank to determine their identities.

In situ hybridization. E12 and E15 embryos were dissected from timepregnant females and processed intact. Spinal cords were dissected from E18, P1, P7, P14, and 3-month-old rats under mammalian Ringer's 


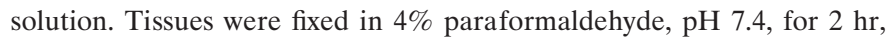
rinsed in PBS, cryoprotected in $20 \%$ sucrose in PBS overnight at $4^{\circ} \mathrm{C}$, embedded in OCT (Tissue-Tek), and frozen in an acetone/dry-ice bath, and $20 \mu \mathrm{m}$ frozen sections were obtained (Leica CM3000 cryostat). Tissues from P1 mutant mice lacking a connexin were used in some experiments as negative controls. These included Cx37-/- [Simon et al. (1997); gift of Dr. D. Paul], Cx40-/- [Simon et al. (1998); gift of Dr. D. Paul], and Cx43-/- [Reaume et al. (1995); obtained from Jackson Labs] animals. All cRNA probes were cloned by RT-PCR from rat spinal cord. The Cx36 probe consisted of the complete rat coding sequence obtained using primers described in Condorelli et al. (1998). The Cx37 probe consisted of a 422 nucleotide (nt) fragment of rat coding sequence (nt 637-1058) (Haefliger et al., 1992); similar results were obtained with a probe generated from a fragment of the $3^{\prime}$ UTR of rat $\mathrm{Cx} 37$. The $\mathrm{Cx} 40$ probe consisted of a $308 \mathrm{nt}$ fragment rat coding sequence (nt 719-1026) (Haefliger et al., 1992). The Cx43 probe consisted of full-length rat coding sequence obtained from Dr. David Paul (Beyer et al., 1987); similar results were obtained with a probe generated from full-length mouse coding sequence, which is $>95 \%$ identical to rat $\mathrm{Cx} 43$ (gift of Dr. Cecilia Lo). The Cx45 (Schwarz et al., 1992), Cx26 (Zhang and Nicholson, 1989), and Cx32 (Paul, 1986) probes consisted of full-length rat coding sequences. Each probe recognized a single band of the expected size in Northern analysis of RNA from E15 rat embryos (see Fig. 7).

Each probe was cloned into pGEM3 (Promega, Madison, WI), and cRNA probes for each connexin were transcribed and labeled with digoxigenin-UTP (Boehringer Mannheim, Indianapolis, IN). A typical $50 \mu \mathrm{l}$ in vitro transcription reaction mixture contained $2 \mu \mathrm{l}(\sim 1 \mu \mathrm{g})$ linearized template DNA, $5 \mu \mathrm{l} 10 \times$ digoxigenin-NTP mix (Boehringer Mannheim), $80 \mathrm{U}$ RNase inhibitor, $10 \mathrm{~mm}$ DTT, $10 \mu \mathrm{l} 5 \times$ transcription buffer (Promega), and 95 U T7 RNA polymerase (Promega). The reaction was performed at $37^{\circ} \mathrm{C}$ for $2 \mathrm{hr}$.

Frozen tissue sections were rinsed with PBS, incubated with acetylation buffer ( $0.926 \mathrm{gm}$ triethanolamine, $112 \mu \mathrm{l} 10 \mathrm{~N} \mathrm{NaOH}, 125 \mu \mathrm{l}$ acetic anhydride, and DEPC $-\mathrm{H}_{2} \mathrm{O}$ to $50 \mathrm{ml}$ ), permeabilized with $1 \%$ Triton $\mathrm{X}-100$ in PBS for $30 \mathrm{~min}$, and rinsed with PBS. Slides were then incubated with prehybridization buffer $(50 \%$ formamide, $4 \times$ SSC, $1 \times$ Denhardt's solution, $10 \%$ dextran sulfate, $250 \mu \mathrm{g} / \mathrm{ml}$ Baker's yeast RNA, and $500 \mu \mathrm{g} / \mathrm{ml}$ herring sperm DNA) at $68-72^{\circ} \mathrm{C}$ for $2 \mathrm{hr}$. cRNA probe $(200-500 \mathrm{ng} / \mathrm{ml})$ was used for hybridization at $68-72^{\circ} \mathrm{C}$ overnight. Moist chambers and coverslips were used to prevent hybridization buffer from evaporating. The next day, the slides were washed with $0.2 \times$ SSC at $68-72^{\circ} \mathrm{C}$ for $1 \mathrm{hr}$, rinsed with PBS, blocked with $1 \%$ BSA- $0.1 \%$ Triton $\mathrm{X}-100$ in PBS for $1 \mathrm{hr}$ at room temperature, and incubated with alkaline phosphatase-conjugated anti-digoxigenin antibody (1:2000 to 1:5000; Boehringer-Mannheim) overnight at $4^{\circ} \mathrm{C}$. Slides were then washed extensively with PBS, equilibrated with $0.1 \mathrm{M}$ Tris- $\mathrm{HCl}, \mathrm{pH} 9.5,0.1 \mathrm{M} \mathrm{NaCl}$, $50 \mathrm{mM} \mathrm{MgCl}_{2}$ for $5 \mathrm{~min}$ at room temperature. A colorimetric reaction for AP was developed and then stopped after signal was determined to be apparent after examination under a dissecting microscope.

Slides were either photographed onto $35 \mathrm{~mm}$ print film and the prints were scanned into a computer, or they were photographed with a Hamamatsu cooled color CCD camera and the images were acquired digitally using a PC-based image processing system (Phase 3 Imaging). Composite images of overlapping fields were made with Adobe Photoshop software.

Northern analysis. Poly(A+) RNAs extracted from E15 rat embryos and spinal cords from P1 wild-type or mutant "knock-out" mice (Cx37-/-, Cx40-/-, and Cx43-/-) were separated on formaldehydecontaining agarose gel and transferred to Nytran Nylon membranes (Schleicher \& Schuell) using TURBOBLOTTER Rapid Downward Transfer Systems (Schleicher \& Schuell). RNAs were then cross-linked to the membrane by UV irradiation. The same templates used to generate cRNA probes for in situ hybridization were used to generate cRNA probes for Northern blot. Strip-EZ RNA stripAble RNA Probe Synthesis and Removal Kits were used to make the probes and later remove them from the membrane. The cRNAs were labeled with ${ }^{32} \mathrm{P}-\mathrm{UTP}$. The hybridization buffer contained $50 \%$ formamide, $5 \times$ SSC, $5 \times$ Denhardt's solution, $500 \mu \mathrm{g} / \mathrm{ml}$ herring sperm DNA, and $0.1 \%$ SDS. The hybridization was performed at $68-72^{\circ} \mathrm{C}$ overnight. The membrane was washed for 20 min with $0.2 \times \mathrm{SSC}$ at $68-72^{\circ} \mathrm{C}$ twice and then exposed to film.

Immunohistochemistry. For some immunostaining experiments, tissues were not fixed before being frozen and sectioned as described above. Frozen tissue sections were picked up on glass slides, rinsed with PBS, blocked with $1 \%$ BSA, $0.1 \%$ Triton X-100 in PBS, and incubated with anti-Cx antibodies at 1:100-1:500 dilution at $4^{\circ} \mathrm{C}$ overnight. The antibod- ies used were anti-Cx26 and anti-Cx43, affinity-purified anti-peptide antibodies derived in rabbit (gift of Dr. Bruce Nicholson); anti-Cx32, mouse monoclonal antibody 7C6C7, raised against amino acid 235-246 in the C terminus of Cx32 [Li et al. (1997); gift of Dr. E. Hertzberg]; anti-Cx37, derived in rabbits against a GST fusion protein containing most of the unique $\mathrm{C}$-terminal region of rat $\mathrm{Cx} 37$ and affinity-purified [Gabriels and Paul (1998); gift of Dr. David Paul]; anti-Cx40, derived in rabbits against a GST fusion protein containing most of the unique $\mathrm{C}$-terminal region of rat $\mathrm{Cx} 40$ and affinity-purified [Gabriels and Paul (1998); gift of Dr. David Paul]; anti-Cx45, derived in rabbit against the C terminal, cytoplasmic domain of mouse $\mathrm{Cx} 45$, and affinity-purified [Steinberg et al. (1994); gift of Dr. Michael Koval]. Negative control experiments were performed by preincubating the anti-Cx45 antibody with the peptide antigen before incubation with E15, P1, and adult rat spinal cord sections; at each of these ages, no immunostaining was observed. Similar results were obtained with a second Cx45 antibody (Chemicon, Temecula, CA). The specificity of each antibody used was evaluated by Western analysis in rat tissue as described below.

Slides were washed with PBS, incubated with appropriate fluorescent secondary antibodies at $4^{\circ} \mathrm{C}$ for 3-4 hr, washed with PBS, and coverslipped in a glycerol-based medium with an anti-fading agent (VectaShield, Vector Labs). At embryonic ages, motor neurons were identified by their location and staining with an antibody against the transcription factor Islet-1 (Tsuchida et al., 1994). At postnatal ages, motor neurons were identified by their location in the ventral horn, large soma size, and primary dendritic arbor after immunostaining using an antineurofilament antibody SMI32 (Sternberger Monoclonals). Slides were examined using the appropriate fluorescence filter sets on a confocal microscope (Leica TCS 4D). Images were processed using Adobe Photoshop and printed on a color printer (Tektronics Phaser 440).

Western analysis. Frozen E15 rat embryos and spinal cords from P1 wild-type or knock-out mice (Cx37-/-, Cx40-/-, and Cx43-/-) were ground into fine powder on dry ice using a mortar and pestle. The powder

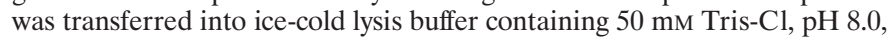
$150 \mathrm{~mm} \mathrm{NaCl}, 0.5 \%$ BSA, $17 \mu \mathrm{g} / \mathrm{ml}$ PMSF, $20 \mu \mathrm{g} / \mathrm{ml}$ leupeptin, $20 \mu \mathrm{g} / \mathrm{ml}$ pepstatin, and $20 \mu \mathrm{g} / \mathrm{ml}$ aprotinin. Lysed samples were spun at $2000 \mathrm{rpm}$ for $10 \mathrm{~min}$ at $4^{\circ} \mathrm{C}$ in an Eppendorf centrifuge 5415C. Supernatant was further spun at $100,000 \times g$ at $4^{\circ} \mathrm{C}$ to pellet the membrane. The membrane preparation was dissolved in lysis buffer with the addition of $1 \%$ SDS and $1 \%$ Triton X-100. Samples were run on SDS-PAGE gels and transferred to polyvinylidene difluoride (PVDF) membranes at $4^{\circ} \mathrm{C}$. PVDF membranes were blocked by $5 \%$ dry milk in PBS-T for $1 \mathrm{hr}$, rinsed with PBS-T, incubated with connexin antibodies $(1: 300-1: 1000)$ for $1 \mathrm{hr}$; rinsed with PBS-T, incubated with HRP-conjugated anti-rabbit antibodies (1:2000-1: 4000) for $1 \mathrm{hr}$; rinsed with PBS-T, and processed for ECL detection (Amersham, Arlington Heights, IL).

\section{RESULTS}

\section{Time course of transient electrical coupling among lumbar motor neurons}

In hemisected spinal cord preparations from $\mathrm{P} 0-\mathrm{P} 8$ rats, motor neurons were identified by the presence of an antidromic action potential after ventral root stimulation (Fig. $1 A$ ). Once a cell was identified, several criteria were used to determine whether the impaled motor neuron might be electrically coupled to other motor neurons. The first of these was a "collision test" (Baker and Llinas, 1971; Connors et al., 1983; Llinas and Sasaki, 1989) in which intracellular current injection was used to elicit an orthodromic action potential in the impaled motor neuron during antidromic ventral root stimulation $(n=35$ cells from 20 P0-P2 rats, $n=10$ cells from $6 \mathrm{P} 3-\mathrm{P} 4$ rats, and $n=7$ cells from $6 \mathrm{P} 7-\mathrm{P} 8$ rats). By decreasing the interval between orthodromic and antidromic stimulation, the antidromic action potential fails to invade the motor neuron soma and dendrites, and an initial segment spike is observed (Fig. 1A). As the stimulation interval is decreased further, the initial segment spike also fails (Fig. 1A). The remaining depolarizing potential is a putative electrical coupling potential, evoked in the impaled cell by antidromic stimulation of other motor axons within the same ventral root.

At $\mathrm{P} 0-\mathrm{P} 2,26$ of 35 cells $(74 \%)$ had coupling potentials identi- 


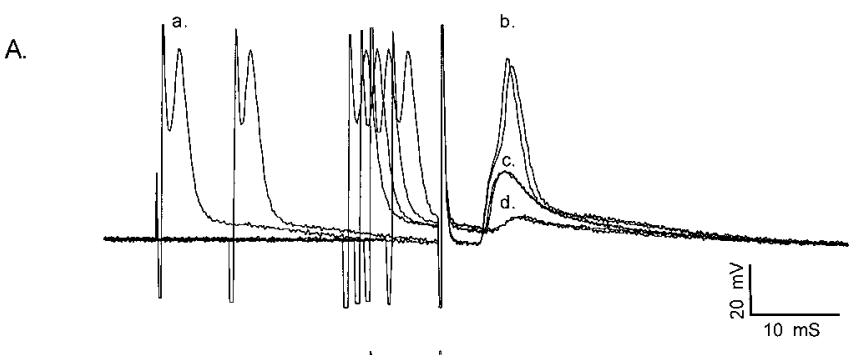

B.

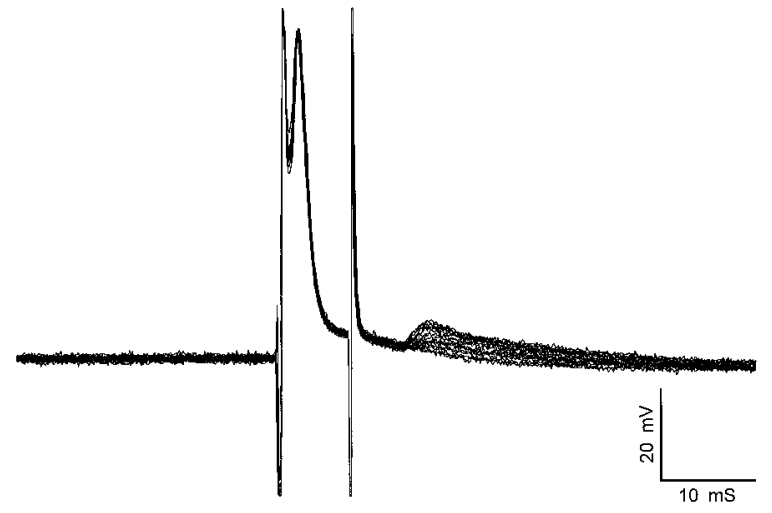

C.

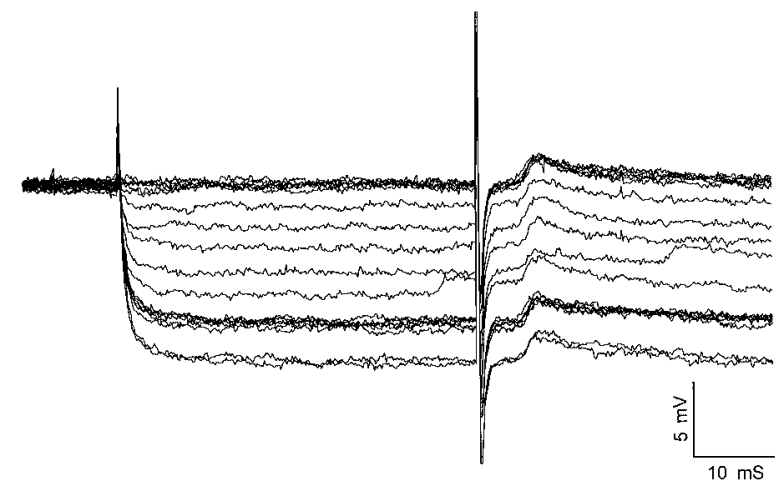

Figure 1. Characterization of electrical coupling among developing motor neurons. Motor neurons were identified by intracellular impalement in hemisected spinal cord preparations from $\mathrm{P} 0-\mathrm{P} 8$ rats by the presence of an antidromic action potential after ventral root stimulation. Shown are coupling potentials characterized in $\mathrm{P} 0-\mathrm{P} 2$ motor neurons identified by antidromic ventral root stimulation. $A$, Intracellular current injection was used to elicit an action potential $(a$.) in the impaled motor neuron during antidromic ventral root stimulation. By adjusting the timing of the intracellular current pulse $(a$.) relative to antidromic ventral root stimulation, the antidromic action potential $(b$. ) elicited by ventral root stimulation failed, revealing an initial segment spike $(c$. $)$. As the interval between the intracellular current pulse and antidromic stimulation was decreased further, the initial segment spike also failed. This failure occurs by collision of the antidromic spike by the intracellularly evoked action potential, which transiently inactivates voltage-gated sodium channels. The remaining depolarizing potential $(d$. $)$ is a putative coupling potential (5.9 mV amplitude, $1.5 \mathrm{msec}$ rise time; $3.9 \mathrm{msec}$ latency from onset of antidromic stimulation; see Table 1 for summary). Calibration: $20 \mathrm{mV}, 10$ msec. $B$, Coupling potential amplitude was graded as the intensity of antidromic stimulation was graded. Partial action potentials, which became apparent as collision tests were performed, occurred in an all-ornothing fashion as antidromic stimulation was graded. Calibration: 20 $\mathrm{mV}, 10 \mathrm{msec}$. $C$, Intracellular hyperpolarization did not affect the amplitude of the coupling potential, in this case detected by straddling threshold for action potential generation. An electrical potential would be insensitive to changes in membrane potential. Coupling potential amplitude $=1.3 \mathrm{mV}$; amplitude after hyperpolarization to $-100 \mathrm{mV}, 1.3 \mathrm{mV}$. Those cells that had coupling potentials as characterized by one or more of these criteria are included in Table 1 . Calibration: $5 \mathrm{mV}, 10 \mathrm{msec}$. fied by this criteria. Coupling potentials were on average $3.2 \pm 0.6$ $\mathrm{mV}$ (mean \pm SEM) (Table 1) in amplitude and were detected between 0.15 and $4 \mathrm{msec}$ after the onset of the antidromically evoked action potential (Fig. 1). Coupling potentials had relatively sharp rise times at these ages $(1.8 \pm 0.1 \mathrm{msec})$ (Table 1$)$, and their waveforms were relatively similar in duration. At P3-P4, 7 of 10 cells $(70 \%)$ had coupling potentials. This proportion is not significantly different from that observed at $\mathrm{P} 0-\mathrm{P} 2(p>0.10$; Fisher exact test). However, the coupling potentials observed in P3-P4 motor neurons were significantly smaller in amplitude $(1.3 \pm 0.4 \mathrm{mV})($ Table 1$)$ than coupling potentials observed in P0-P2 rats ( $p<0.005$, Student's $t$ test). The coupling potentials observed at P3-P4 had a similar mean rise time $(1.8 \pm 0.5 \mathrm{msec}$; not significantly different; $p>0.5$, Student's $t$ test) (Table 1) but a larger range of rise times than those observed at P0-P2. At $\mathrm{P} 7-\mathrm{P} 8$, none of the cells recorded had coupling potentials detectable after collision of antidromic and orthodromic action potentials. In some cases, motor neurons exhibiting coupling potentials were further characterized in one or more of three ways to determine whether these potentials reflected electrical communication among motor neurons. The first characterization involved determining whether grading the intensity of antidromic stimulation resulted in changes in the amplitude of the coupling potential (Fig. 1B). This was performed in most motor neurons with coupling potentials and was necessary because partially blocked action potentials (initial segment or M-spikes) (Llinas and Sasaki, 1989), which became apparent as the collision test was performed, could be mistaken for large coupling potentials. However, partial spikes occurred in an all-or-nothing fashion as antidromic stimulation was graded, whereas coupling potentials were always graded in amplitude as the intensity of antidromic stimulation was altered, as would be expected if several antidromically stimulated motor neurons gave rise to the coupling potential in the impaled cell.

The effect of intracellular hyperpolarization on the amplitude of the coupling potential was also evaluated in $\mathrm{P} 0-\mathrm{P} 2$ motor neurons with coupling potentials ( $n=7$ cells). Electrical potential amplitude would be insensitive to membrane potential, unless the gap junction proteins were strongly gated by transmembrane voltage (cf. Spray et al., 1985; Verselis et al., 1986; Paul et al., 1991; Moreno et al., 1994). In seven of the seven cells evaluated in this fashion, no changes in the amplitude of the coupling potential were observed during intracellular hyperpolarization from rest to more than $-100 \mathrm{mV}$ (Fig. 1C). The response to antidromic ventral root stimulation also included a longer latency component, presumably attributable to activation of Renshaw neurons. The amplitude of these potentials was always sensitive to changes in membrane potential (data not shown).

In four $\mathrm{P} 0-\mathrm{P} 2$ motor neurons, the effect of high-frequency stimulation $(10-100 \mathrm{~Hz})$ on the coupling potential was also evaluated. Unlike chemical synaptic potentials, electrical potentials do not fail with high-frequency stimulation (Llinas and Sasaki, 1989). In each of the cells evaluated with high-frequency stimulation, no failure of the coupling potential was observed.

Taken together, these data suggest that the prevalence and strength of coupling potentials among rat lumbar spinal motor neurons decreases during the first postnatal week and that electrical coupling potentials are undetectable after this time.

\section{Coupling potentials are abolished by a gap junction blocker}

To determine whether coupling potentials could be reversibly abolished by a gap junction blocker such as halothane (Burt and 
Table 1. Characterization of motor neuron electrical and dye coupling

\begin{tabular}{|c|c|c|c|c|c|c|c|}
\hline $\begin{array}{l}\text { Age } \\
\text { (days) }\end{array}$ & $\begin{array}{l}\text { Number of } \\
\text { motor neu- } \\
\text { rons identi- } \\
\text { fied and } \\
\text { characterized }\end{array}$ & $\begin{array}{l}\text { Number of } \\
\text { motor neurons } \\
\text { with coupling } \\
\text { potentials }\end{array}$ & $\begin{array}{l}\text { Coupling po- } \\
\text { tential ampli- } \\
\text { tude, } \mathrm{mV} \\
\text { (mean } \pm \\
\text { SEM) }\end{array}$ & $\begin{array}{l}\text { Coupling poten- } \\
\text { tial rise time, } \\
\text { msec (mean } \pm \\
\text { SEM) }\end{array}$ & $\begin{array}{l}\text { Number of dye- } \\
\text { labeled cells } \\
\text { per cluster } \\
(\text { mean } \pm \text { SEM; } \\
n)\end{array}$ & $\begin{array}{l}\text { Soma diame- } \\
\text { ter of dye- } \\
\text { labeled cells } \\
\text { per cluster } \\
(\text { mean } \pm \\
\text { SEM) }\end{array}$ & $\begin{array}{l}\text { Distribution } \\
\text { rostral-caudal/ } \\
\text { dorsal-ventral/ } \\
\text { medial-lateral, } \\
\mu \mathrm{m}\end{array}$ \\
\hline $\mathrm{P} 0-\mathrm{P} 2$ & 35 & 26 & $3.4 \pm 0.5$ & $1.8 \pm 0.1$ & $6.1 \pm 1.8(10)$ & $31.3 \pm 1.2$ & 139/130/96 \\
\hline P3-P5 & 10 & 7 & $1.3 \pm 0.6^{a}$ & $1.8 \pm 0.5$ & $2.2 \pm 0.3(5)^{a}$ & $31.1 \pm 1.6$ & $70 / 70 / 50$ \\
\hline P6-P8 & 7 & 0 & Not applicable & Not applicable & $1.2 \pm 0.2(6)^{a}$ & $33.8 \pm 2.0$ & Not applicable \\
\hline
\end{tabular}

${ }^{a}$ Significantly different from value at $\mathrm{P} 0-\mathrm{P} 2, p>0.005$, Student's $t$ test.

Spray, 1989; Peinado et al., 1993), hemisected spinal cords were superfused with halothane-saturated Ringer's solution after characterization of coupling potentials as described above $(n=4$ cells). A collision test was used to determine whether a coupling potential was present and whether superfusion with halothanesaturated Ringer's solution resulted in coupling potentials being reversibly abolished.

In each case, the coupling potential observed during a collision test (Fig. $2 A$ ) was observed to steadily decrease in amplitude and become abolished within 10-15 min of perfusion with halothanesaturated Ringer's solution (Fig. $2 B$ ). No change in resting membrane potential was observed during perfusion with halothanesaturated Ringer's. In two motor neurons, subsequent washout of halothane with normal Ringer's led to a complete recovery of the coupling potential amplitude (Fig. 2C). This experiment further suggests that electrical coupling potentials observed in motor neurons are mediated by gap junctions.

\section{Extent of dye coupling among lumbar motor neurons}

The intracellular recording and pharmacology experiments reported here and previously (Fulton et al., 1980; Walton and Navarette, 1991) showed that neonatal lumbar motor neurons are transiently electrically coupled, and this disappears during the first days after birth. To understand the possible biological roles of transient gap junctional coupling among motor neurons, we compared the presence of electrical potentials with the presence of dye coupling. One issue of interest was whether few cells are strongly coupled or, alternatively, whether many cells are weakly coupled. A second issue of interest was to determine the spatial extent of dye coupling.

To address these issues, we used intracellular iontophoretic injection of Neurobiotin, a low molecular weight compound that passes across gap junctions (Kita and Armstrong, 1991) into single identified motor neurons from P0-P2 ( $n=10$ cells), P3-P5 ( $n=5$ cells), and P7-P8 ( $n=6$ cells) rats. Only one motor neuron was injected per spinal cord. After waiting $2 \mathrm{hr}$ to allow dye to diffuse from one cell to another, spinal cords were fixed, sectioned, and stained with strepavidin. Sections were then examined with confocal microscopy, and the number and spatial distribution of dye-labeled motor neurons was determined.

At $\mathrm{P} 0-\mathrm{P} 2$, each injected motor neuron had a coupling potential as determined by one or more of the criteria described above. Injected motor neurons were identified by strong Neurobiotin labeling in the cell body and throughout their extensive dendritic arbor (Fig. 3), and approximately one-third of injected neurons ( $n=3$ cells) had a Neurobiotin-labeled axon that exited a ventral root. In each case, 1-18 labeled cells were observed surrounding the injected motor neuron $(6.1 \pm 1.8$ mean \pm SEM) (Fig. 4 ; Table 1). These cells had large soma, ranging from 22 to $44 \mu \mathrm{m}$ in

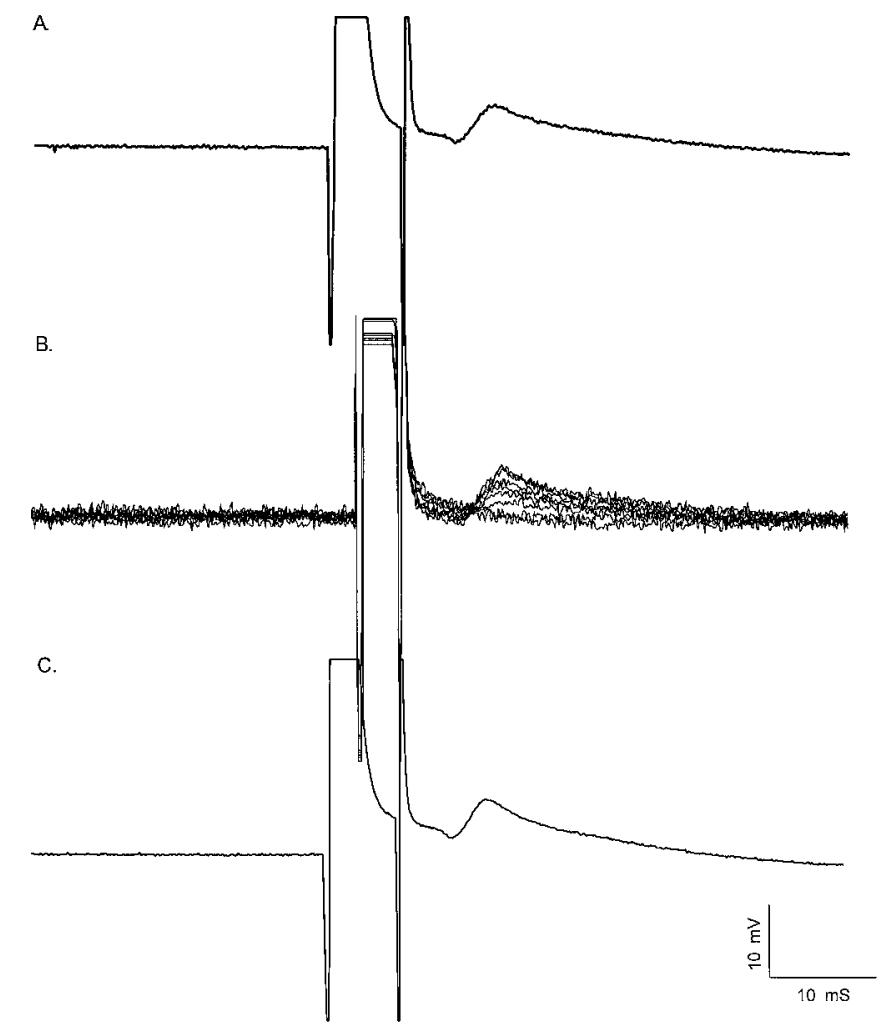

Figure 2. Coupling potentials are abolished by halothane, a gap junction blocker. To determine whether coupling potentials could be reversibly abolished by a gap junction blocker, preparations were superfused with halothane-saturated Ringer's solution after characterization of coupling potentials as shown in Figure 1. $A$, A collision test was initially used to determine whether a coupling potential was present. Coupling potential, $5.6 \mathrm{mV}$; average of 10 sweeps, P0 spinal cord. $B$, After several minutes of exposure to halothane-saturated Ringer's, coupling potentials were abolished. Shown are eight successive sweeps illustrating the decrease in coupling potential amplitude until no potential could be detected. No change in resting membrane potential was observed during perfusion with halothane-saturated Ringer's. $C$, Washout of halothane with normal Ringer's led to a complete recovery of the coupling potential amplitude, 5.6 $\mathrm{mV}$; average of 20 sweeps $15 \mathrm{~min}$ after replacement of halothane with normal Ringer's. Calibration: $10 \mathrm{mV}, 10 \mathrm{msec}$.

diameter (Table 1), and in many cases primary and secondary dendrites were also labeled. We compared the size distribution of dye-labeled cells with the size distribution of neurons in the ventral horn retrogradely labeled after dye injection into hindlimb muscles of postnatal rats (Swett et al., 1986; Hashizume et al., 1988; Westerga and Gramsbergen, 1992) and from our own observations with retrograde labeling with FluoroGold (Q. Chang and R. Balice-Gordon, unpublished data). On the basis of 

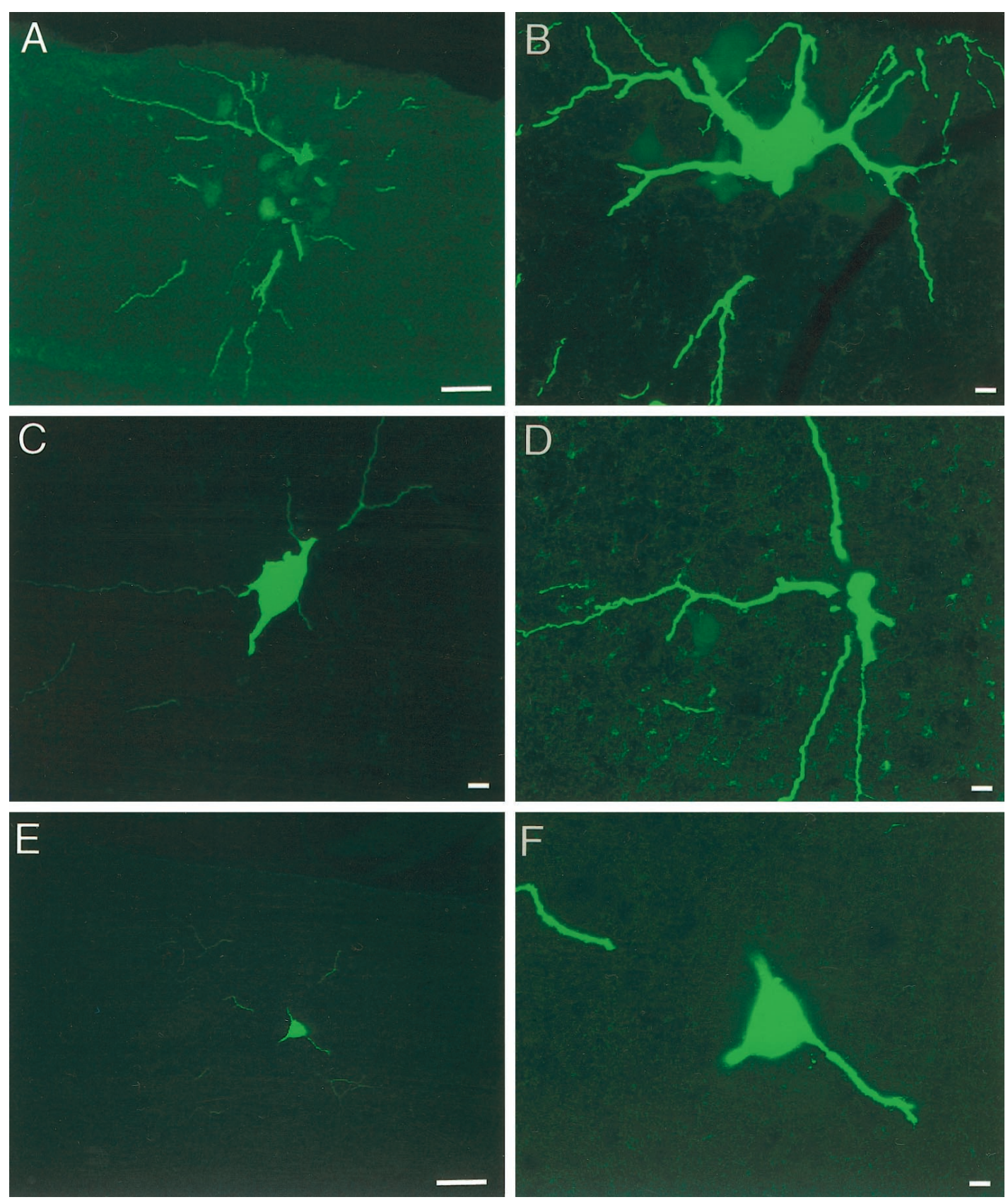

Figure 3. Developing motor neurons are extensively dye coupled around the time of birth. The number of dye-labeled cells was determined 2-4 hr after injection of a single characterized motor neuron with Neurobiotin followed by histology. $A$, Single plane projection of confocal stack of images from a P2 spinal cord, showing ventral and lateral location of dendrites of injected motor neuron and 10 additional Neurobiotin-labeled cells. Ventral edge of section is shown at top of panel. Scale bar, $25 \mu \mathrm{m}$. B. Single plane projection of confocal stack of images of injected motor neuron cell body shown in $A$ (adjacent section), with its proximal dendrites and surrounded by five additional Neurobiotin-labeled cells. A total of 19 labeled cells were in this cluster, spanning five adjacent sections of $20 \mu \mathrm{m}$ each. Scale bar, $10 \mu \mathrm{m}$. $C$, Single plane projection of confocal stack of images from a P4 spinal cord, showing cell body and proximal dendrites of injected motor neuron. Scale bar, $10 \mu \mathrm{m}$. $D$, Single plane projection of confocal stack of images of an adjacent section, showing one additional Neurobiotin-labeled cell body. Scale bar, $10 \mu \mathrm{m}$. E, Single plane projection of confocal stack of images from a P7 spinal cord, showing single cell body and some of the dendritic arbor of the injected motor neuron. Ventral edge of the section is at top of panel. Scale bar, $25 \mu \mathrm{m}$. F, Single plane projection of confocal stack of images at higher magnification, confirming that only one Neurobiotin-labeled cell body is present. Scale bar, $10 \mu \mathrm{m}$.

their large diameters and dendritic morphology, motor neurons with coupling potentials are dye coupled to other motor neurons, and these are likely to be $\alpha$ motor neurons. There was no relationship between coupling potential amplitude in the injected motor neuron with the number of dye-labeled cells per cluster $(r=-0.16, n=10 ; p>0.10)$.
The distribution of dye-labeled motor neurons was spatially restricted within the medial or lateral columns of the ventral horn. In P0-P2 spinal cords, each dye-labeled cluster of motor neurons occupied a mean volume of $139 \times 130 \times 96 \mu \mathrm{m}$ in the rostralcaudal, dorsal-ventral, and medial-lateral dimensions of the ventral horn, respectively (Fig. 5; Table 1). The implications of the 


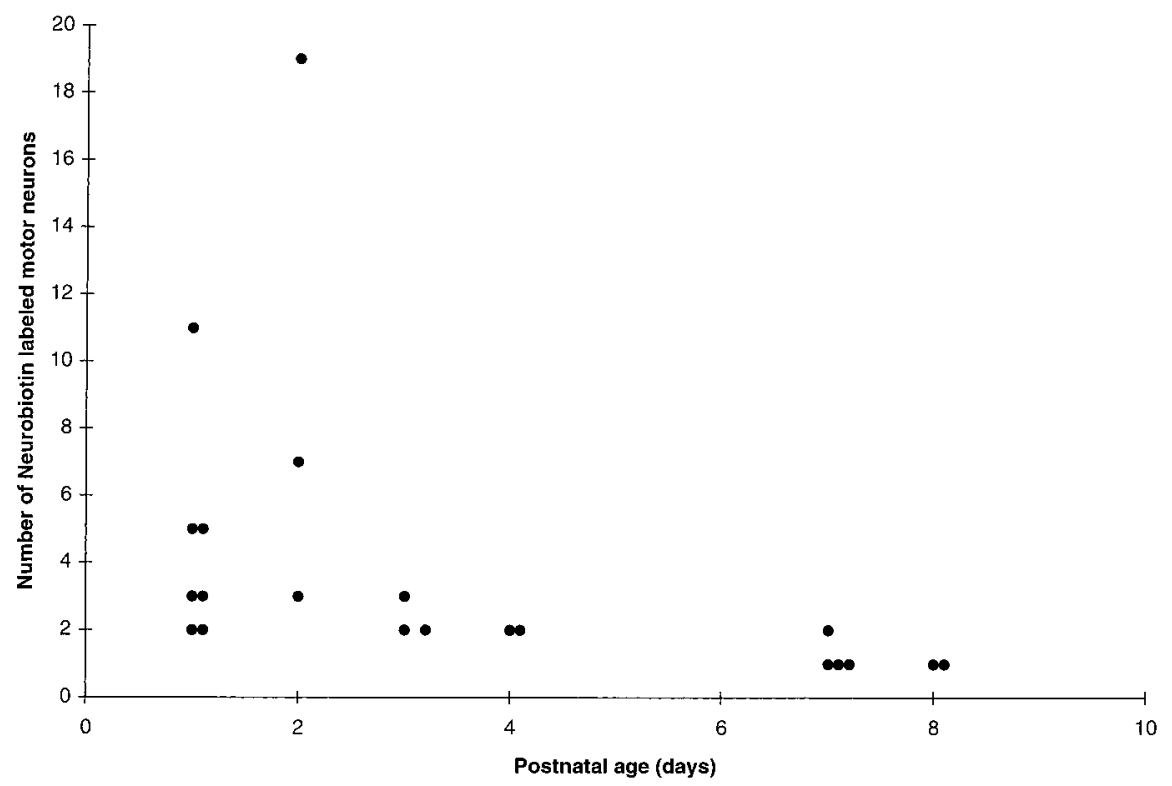

Figure 4. Extent of dye coupling among motor neurons during the first week after birth. The number of cells in each dye-labeled motor neuron cluster is shown plotted against postnatal age in days. Between P0-P2 and P7-P8, there is a sharp decrease in the number of Neurobiotinlabeled motor neurons per cluster. compact distribution of dye-labeled motor neurons are considered below.

At P3-P5, three of five motor neurons injected had a coupling potential as identified by one or more of the criteria described above. In these cases, injection of a single motor neuron resulted in dye labeling of two or three motor neurons $(2.3 \pm 0.3$ mean \pm SEM) (Fig. 4; Table 1), identified by their large diameter (26-44 $\mu \mathrm{m})$ (Table 1) and extensive dendritic arbor (Fig. 3). In two motor neurons, no coupling potential was detected after a collision test. In both of these cases, injection of a single motor neuron resulted in dye labeling of two cells. This suggests that, as has been reported in brainstem and cortex (Mazza et al., 1992; Yuste et al., 1992; Peinado et al., 1993; Kandler and Katz, 1995; Rorig and Sutor, 1996; Nadarajah and Parnavelas, 1999), electrical coupling becomes undetectable before the disappearance of dye coupling. Although it is possible that electrical and dye coupling are regulated separately, it is more likely that this reflects the difficulty in detecting attenuated electrical potentials because gap junctions become electrotonically removed from the cell body as dendrites grow. As in $\mathrm{P} 0-\mathrm{P} 2$ spinal cords, each dye-labeled cluster of motor neurons in P3-P5 spinal cord was compact, occupying a mean volume of $70 \times 70 \times 50 \mu \mathrm{m}$ in the rostral-caudal, dorsal-ventral, and medial-lateral dimensions of the ventral horn, respectively (Fig. 5; Table 1).

By P7-P8, none of the motor neurons injected ( 0 of 7 ) had a coupling potential as identified by collision test or other criteria. In six of these cases, injection of a single motor neuron resulted in dye labeling of a single cell (Figs. 3, 4; Table 1). In one case, no coupling potential was detected, but two dye-labeled neurons were observed after intracellular injection of Neurobiotin. These data suggest that shortly after birth, as observed for electrical coupling, there is a sharp reduction in the extent of dye coupling among lumbar motor neurons.

Two control experiments were performed to rule out dye uptake that might have artifactually resulted in more than one motor neuron becoming labeled by Neurobiotin. In three P0-P2 spinal cords, Neurobiotin was iontophoretically deposited extracellularly into the ventral horn at the location where extracellular field potentials were identified after antidromic ventral root stimulation. In none of these cases was intracellular labeling of motor neurons or other cells observed, although in some sections nonspecific labeling of capillaries was seen.

We also evaluated whether Neurobiotin leaking out of the intracellular electrode, or being inadvertently iontophoresed as intracellular current was injected for physiological characterization of electrical coupling, could result in motor neuron dye labeling, and thus result in a cluster being detected. In three $\mathrm{P} 0-\mathrm{P} 2$ spinal cords, four to five motor neurons were impaled and characterized with a Neurobiotin-filled intracellular electrode, but Neurobiotin was not intentionally iontophoresed. In none of these spinal cords were dye-labeled motor neurons or other cells detected. The results of these control experiments suggest that the clusters of dye-labeled motor neurons that we observed in neonatal spinal cords were caused by intercellular gap junctional communication as opposed to nonspecific dye uptake.

\section{Developing motor neurons express five gap junction proteins}

Given that electrical and dye coupling disappear shortly after birth, we reasoned that the temporal and spatial expression patterns of gap junction proteins, called connexins, might also be developmentally regulated. We determined the repertoire of motor neuron connexin expression using RT-PCR, in situ hybridization, and immunostaining. Using primers designed to specifically amplify each of the 13 known rodent connexins, E15 rat motor neurons were purified and analyzed by RT-PCR. Motor neuron preparations were determined to be homogeneous if $>98 \%$ of the cells were immunopositive after staining with an anti-Islet-1 antibody (Tsuchida et al., 1994). For example, in one preparation, cells were counted from 10 independent fields; 164 of 165 cultured cells were positive for Islet-1.

Using primers specific for Cx36, Cx37, Cx40, Cx43, and Cx45, PCR products of the expected size were typically observed in the motor neuron cDNA lanes but not RNA lanes (Fig. 6). Primers specific for Cx36 amplified a 979 bp band in motor neuron and eye cDNA (Condorelli et al., 1998). Primers specific for Cx37, Cx40 (Haefliger et al., 1992), Cx43 (Beyer et al., 1987), and Cx45 (Schwarz et al., 1992) amplified 422, 308, 292, and 1217 bp bands, respectively, in motor neuron and heart cDNA. In contrast, primers against the other known rodent connexins amplified 


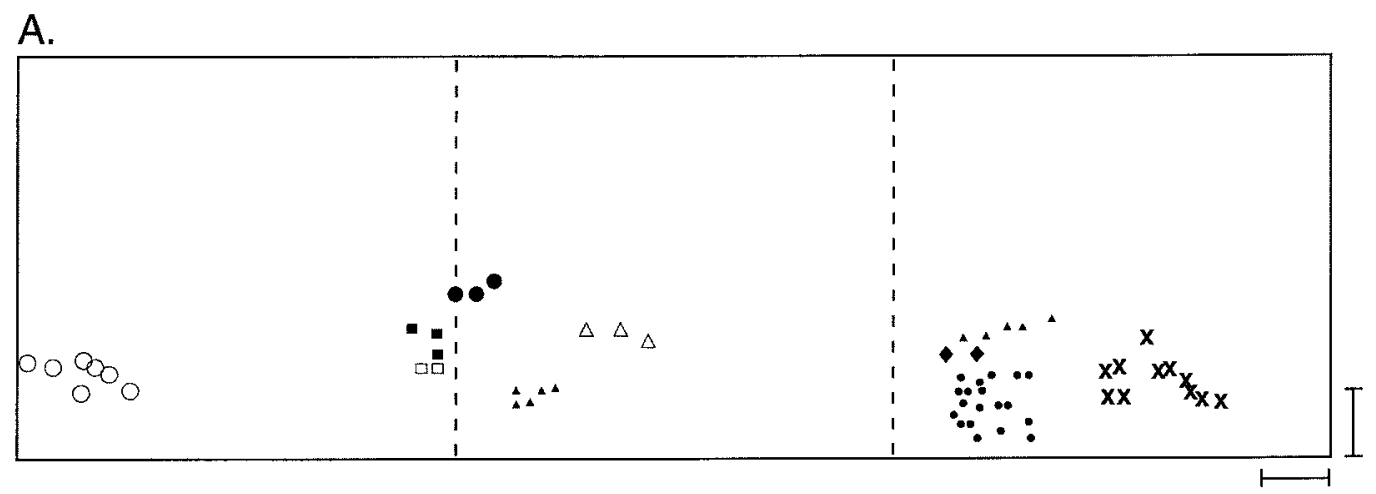

B.

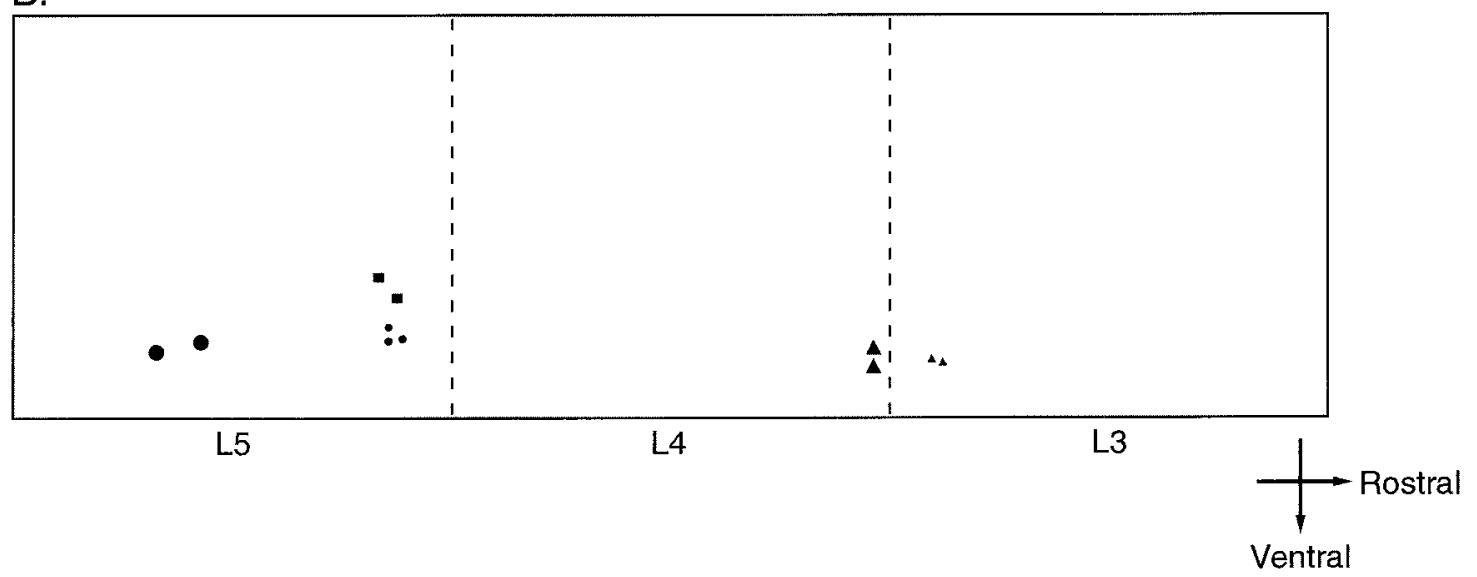

Figure 5. Distribution of dye-labeled neurons suggests limited spatial extent of gap junctional coupling after birth. The distribution of dye-labeled motor neurons is shown for each cluster from P0-P2 $(A)$ and P3-P4 $(B)$ spinal cord segments L3, L4, and L5. Each cluster is represented by a different symbol. In P0-P2 spinal cords, each dye-labeled cluster of motor neurons occupied a mean volume of $139 \times 130 \times 96 \mu \mathrm{m}$ in the rostral-caudal, dorsal-ventral, and medial-lateral dimensions of the ventral horn, respectively (Table 1). The dimensions of individual motor pools at these ages are more than twice as large. Similarly, at P3-P4, each dye-labeled cluster of motor neurons occupied a mean volume of $70 \times 70 \times 50 \mu \mathrm{m}$ in the rostral-caudal, dorsal-ventral, and medial-lateral dimensions of the ventral horn, respectively (Table 1). Given that there is relatively little overlap among motor pools in the rat ventral spinal cord, the distribution of dye-labeled motor neurons strongly suggests that, after birth at least, dye coupling is present among motor neurons that innervate the same skeletal muscle. Scale bar, $100 \mu \mathrm{m}$.

bands of predicted size from tissues known to express that particular connexin (for example, skin, heart, eye, testis, and liver) but failed to amplify the same size band in motor neurons. In each case, PCR products were eluted from gels, cloned, and sequenced to verify their identity. In the case of $\mathrm{Cx} 26$, primers amplified a weak band of the predicted size ( 365 base pairs) from motor neuron cDNA (Fig. 6). This is very likely to be attributable to genomic DNA contamination, because a weak band of the same size is also present in the motor neuron RNA lane, and an in situ hybridization signal was not observed in motor neurons with Cx26-specific cRNA probes (see below). In the case of $\mathrm{Cx} 33$, Cx33-specific primers amplified a strong band of the expected size (476 base pairs) from testis cDNA but not from motor neuron cDNA. There is a $\sim 600$ base pair band in the motor neuron cDNA lane that is very likely to be caused by nonspecific amplification, because the sequence of this band was not homologous to $\mathrm{Cx} 33$ or any other known connexin.

The five connexins identified by RT-PCR from purified embryonic motor neurons were also detected from RNA extracted from P1 spinal cord (data not shown). Cx26 and Cx32, which are known to be expressed in meninges, ependymal cells, and glia, (for review, see Bruzzone and Ressot, 1997) were also detected. These results show that five connexins are expressed by embry- onic motor neurons and are expressed in the ventral spinal cord at birth.

\section{Spatial and temporal patterns of motor neuron connexin expression}

To determine the spatial and temporal patterns of connexins expressed by motor neurons that may contribute to the formation of functional gap junctions during development, in situ hybridization was performed in cross sections of lumbar spinal cord from rats ranging from E12 to 3 months of age. cRNA probes against each of the five connexins that were positive in RT-PCR from purified E15 motor neurons were used, as well as cRNA probes against Cx26 and Cx32, identified by RT-PCR from P1 spinal cord. Northern blot analysis showed that each cRNA probe used recognized a single band of the predicted size and, in the case of $\mathrm{Cx} 37, \mathrm{Cx} 40$, and $\mathrm{Cx} 43$, did not recognize the same size band from RNA extracted from mutant mice lacking those genes (Fig. 7A). The Cx32 cRNA probe was characterized previously (Bergoffen et al., 1993), and we confirmed that it recognized a single band from spinal cord of P1 wild-type mice but did not recognize a band from the spinal cord of $\mathrm{P} 1$ mutant mice lacking Cx32 (data not shown). As negative controls, sections from P1 spinal cord from $\mathrm{Cx} 37-/-, \mathrm{Cx} 40-/-$, and $\mathrm{Cx} 43-/-$ mice were 

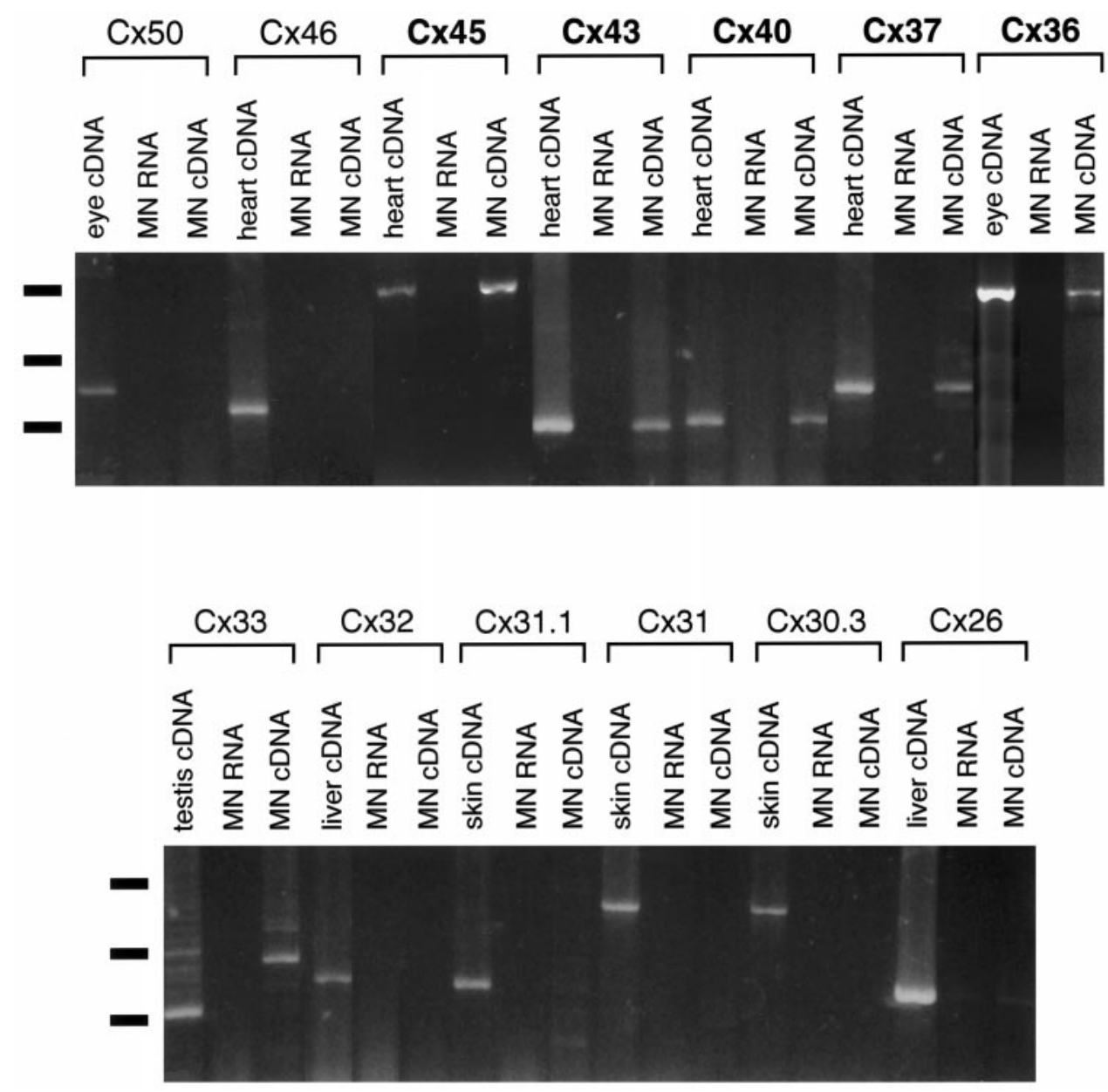

Figure 6. RT-PCR analysis of connexins expressed by embryonic motor neurons and in neonatal spinal cord. RT-PCR analysis was performed on motor neuron RNA. PCR products were amplified using primers for each of the 13 known rodent connexins. Bands were typically observed in the motor neuron cDNA lanes, but not RNA lanes, using primers specific for Cx36, Cx37, Cx40, Cx43, and Cx45. Primers specific for Cx36 amplified a $979 \mathrm{bp}$ band in motor neuron and eye cDNA. Primers specific for Cx37, Cx40, Cx43, and $\mathrm{Cx} 45$ amplified 422, 308, 292, and 1217 bp bands, respectively, in motor neuron and heart cDNA. In contrast, primers against the other known rodent connexins amplified the predicted size band from tissues known to express that particular connexin (for example, skin, heart, liver, eye, and testis) but failed to amplify the same size band in motor neurons. In each case, PCR products were eluted from gels, cloned, and sequenced to verify their identity. Horizontal lines at left indicate markers (from top to bottom, 1.2, 0.6, and $0.3 \mathrm{kB})$. probed with Cx37-, Cx40-, or Cx43-specific probes, respectively, and for each connexin, hybridization using sense RNA probes was performed at each time point. These controls revealed no hybridization signal (data not shown).

Cx36, Cx37, Cx40, Cx43, and Cx45 were observed to be widely expressed in the neural tube and ventricular zone from E12 to E15 and throughout the spinal cord, particularly in the dorsal horn, at later stages. Although these connexins appear to be differentially developmentally regulated in these structures, here we focus on expression only in ventral horn motor neurons. In experiments in E12-E18 animals, ventral spinal cord regions containing motor neurons were identified by their expression of mRNA for the transcription factor Islet-1 (Tsuchida et al., 1994) in serial sections (data not shown). Because motor neurons are smaller at embryonic compared with adult ages, more motor neurons are apparent in a cross section from an embryonic compared with an adult spinal cord; the compact distribution of motor neurons at embryonic ages made it difficult to reliably quantify the proportion of motor neurons positive for each connexin. However, the extent of expression of each connexin (Figs. 8,9 ) was qualitatively evaluated (Table 2 ). Although Islet-1 is not expressed after birth (Tsuchida et al., 1994), postnatal and adult motor neurons are easily identified by their large diameter, distinct morphology, and ventral location, and thus the proportion of motor neurons with a clearly visible nucleus that were positive for each connexin transcript was determined after birth (Table 2) in many cross sections throughout the lumbar spinal cord of at least three animals for each connexin.
The temporal and spatial expression patterns of $\mathrm{Cx} 36, \mathrm{Cx} 37$, and $\mathrm{Cx} 43$ were similar, in that these connexins were expressed in the majority of motor neurons from E15 through adulthood (Fig. 8). Expression was also observed in the dorsal root ganglia and in scattered cells in the dorsal horn. Surprisingly, expression was maintained in a substantial population of adult motor neurons (89-93\%) (Table 2), despite the lack of functional gap junctional coupling after $\mathrm{P} 3-\mathrm{P} 4$. To determine whether the proportion of motor neurons expressing Cx36, Cx37, and Cx43 transcripts varied among the medial, dorsolateral, or ventrolateral motor columns, the number of positive and negative motor neurons was counted in each of these regions in P1-adult lumbar spinal cord cross sections. No differences were observed in medial compared with dorsolateral or ventrolateral motor columns (data not shown). These data show that the motor neuronal expression of Cx36, Cx37, and Cx43 is relatively homogeneous, spatially as well as temporally, from embryonic life through adulthood.

In contrast, a decrease in the proportion of motor neurons positive for $\mathrm{Cx} 45$ and $\mathrm{Cx} 40$ transcripts was observed from embryonic to adult life. At E12, Cx45 and Cx40 were expressed relatively uniformly throughout the neural tube (data not shown), and from E15 to E18, these connexins were expressed in most motor neurons (Fig. 9; Table 2). After birth, however, the proportion of motor neurons expressing Cx45 mRNA gradually decreased, from $83 \%$ at birth to $48 \%$ in adult rat spinal cord (Table 2). Cx40 expression decreased more dramatically. Although at birth $91 \%$ of motor neurons were positive for $\mathrm{Cx} 40$ transcripts, this decreased to $33 \%$ at $\mathrm{P} 7$, and only $7 \%$ of motor 
A.

\section{$\begin{array}{lllll}\text { Cx36 } & \text { Cx37 } & \text { Cx40 } & \text { Cx43 } & \text { Cx45 }\end{array}$}
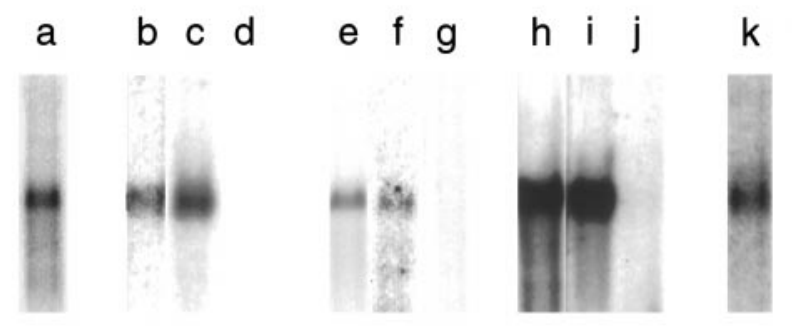

B.

\section{Cx40}

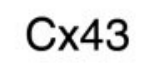

\section{Cx45}
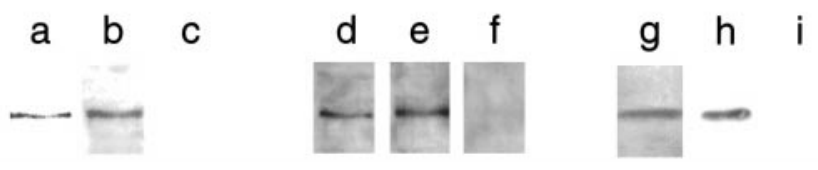

Figure 7. Northern and Western blot analyses of connexin-specific reagents. $A$, Shown are Northern blots of poly $\left(\mathrm{A}^{+}\right)$RNA extracted from E15 rat embryos (lanes $a, b, e, h$, and $k$ ), spinal cords of wild-type P1 mice $(c, f$, and $i)$, or spinal cords of mutant $\mathrm{Cx} 37-/-(d), \mathrm{Cx} 40-/-(g)$, and $\mathrm{Cx} 43-/-(j) \mathrm{P} 1$ mice. A rat Cx36 cRNA probe detected a single band of $2.9 \mathrm{~kb}$ in E15 rat embryos $(a)$. A rat Cx37 cRNA probe detected a single $1.5 \mathrm{~kb}$ band in E15 rat embryos $(b)$ and wild-type P1 mouse spinal cords (c). No band was detected in spinal cords from P1 Cx37-/- mouse $(d)$. A rat $\mathrm{Cx} 40$ cRNA probe detected a single $3.4 \mathrm{~kb}$ band in E15 rat embryos $(e)$ and wild-type P1 mouse spinal cords $(f)$. No band was detected in spinal cords from $\mathrm{P} 1 \mathrm{Cx} 40-/-$ mouse $(g)$. A rat $\mathrm{Cx} 43$ cRNA probe detected a single $3 \mathrm{~kb}$ band in E15 rat embryos $(h)$ and wild-type P1 mouse spinal cords $(i)$. No band was detected in spinal cords from P1 Cx43-/- mouse $(j)$. A rat $\mathrm{Cx} 45$ cRNA probe detected a single $2.2 \mathrm{~kb}$ band in E15 rat embryos $(k)$. $B$, Shown are Western blots of membrane preparations from E15 rat embryos (lanes $a, d$, and $g$ ), spinal cords from wild-type $\mathrm{P} 1$ mice $(b, e)$, spinal cords from mutant $\mathrm{P} 1 \mathrm{Cx} 40-/-(c)$ and Cx43-/- $(f)$ mice, or HeLa cells transfected with Cx45 cDNA $(h)$ and untransfected HeLa cells $(i)$. The anti-Cx40 antibody recognized a single $\sim 40 \mathrm{kDa}$ band in E15 rat embryos $(a)$ and wild-type P1 mouse spinal cord (b). No band was detected in P1 Cx40-/- mouse spinal cord $(c)$. The anti-Cx43 antibody recognized a single band of $\sim 43 \mathrm{kDa}$ in $\mathrm{E} 15$ rat embryos $(d)$ and wild-type P1 mouse spinal cords $(e)$. No band was detected in $\mathrm{P} 1 \mathrm{Cx} 43-/-$ mouse spinal cords $(f)$. The anti-Cx45 antibody recognized a single band of $\sim 45 \mathrm{kDa}$ in E15 rat embryos $(g)$ and Cx45-transfected HeLa cells $(h)$. No band was detected in untransfected HeLa cells $(i)$.

neurons were observed to be positive in adults (Fig. 9; Table 2). As observed for $\mathrm{Cx} 36, \mathrm{Cx} 37$, and $\mathrm{Cx} 43$, no differences were observed in the expression of $\mathrm{Cx} 45$ or $\mathrm{Cx} 40$ transcripts in medial, dorsolateral, or ventrolateral motor columns after birth. Cx45 and Cx40 mRNA was also detected in dorsal root ganglia and in scattered cells in the dorsal horn.

The expression patterns of $\mathrm{Cx} 26$ and $\mathrm{Cx} 32$, identified in RTPCR analyses from P1 spinal cord, were also examined. These connexins are widely expressed in developing and adult rodent CNS by meningeal and ependymal cells and glia (for review, see Dermietzel and Spray, 1993; Nadarajah and Parnavelas, 1999). Consistent with this, Cx32 and Cx26 mRNA were expressed in meninges, in ependymal cells surrounding the ventricles, or in scattered, small-diameter cells throughout the gray and white matter in P1 through adult spinal cord but were not observed to be expressed in motor neurons at any age examined (data not shown).
Taken together, these results suggest that developing motor neurons express a repertoire of five connexins and that the spatial patterns of expression appear relatively homogeneous across medial, dorsolateral, and ventrolateral motor columns. Two temporal patterns of connexin expression were observed. The proportion of motor neurons expressing of $\mathrm{Cx} 45$ and $\mathrm{Cx} 40$ mRNA decreased after birth, with $\mathrm{Cx} 40$ widely expressed throughout the neural tube at E12 but expressed by $<10 \%$ of adult motor neurons. The expression of $\mathrm{Cx} 36, \mathrm{Cx} 37$, and $\mathrm{Cx} 43$ was widespread throughout development, and expression of each of these connexin transcripts was detected in the majority of adult motor neurons. The implications of the apparent mismatch between electrical and dye coupling and gap junction protein expression are discussed below.

\section{Expression of connexin proteins in developing and adult motor neurons}

To compare the spatial and temporal patterns of connexin mRNA expression with that of connexin proteins, spinal cord cross sections were immunostained with anti-connexin antibodies. Motor neurons were identified by Islet-1 immunoreactivity (Fig. 10) (Tsuchida et al., 1994) in spinal cord from E12-E18 rats or after anti-neurofilament staining by their large soma size, dendritic morphology, and location in spinal cord from P1-adult rats. The specificity of anti-Cx40, -Cx43, and -Cx45 antibodies was characterized by Western blot analysis (Fig. $7 B$ ), which in each case revealed a single band of the expected molecular mass in spinal cord. In the case of $\mathrm{Cx} 40$ and $\mathrm{Cx} 43$, no band was detected in protein isolated from spinal cord of mutant mice lacking one of these connexins. $\mathrm{Cx} 36$ and $\mathrm{C} \times 37$ protein expression were not characterized; in the case of $\mathrm{Cx} 36$, specific antibodies are not yet available. In the case of Cx37, a polyclonal, affinity-purified antiCx37 antibody revealed a single band of $37 \mathrm{kDa}$ in Western blot analysis (data not shown). However, although punctate staining was observed in the spinal cord and in motor neurons from P1-adult rat and wild-type adult mice, similar staining was observed in motor neurons in adult Cx37-/- mice. Thus it seems likely that this antibody detects other epitopes in spinal motor neurons.

$\mathrm{Cx} 40, \mathrm{Cx} 43$, and $\mathrm{Cx} 45$ protein appeared to be expressed in similar temporal and spatial patterns as their mRNA transcripts. From E12-E18, Cx40, Cx43, and Cx45 immunoreactivity was localized to most if not all Islet-1-positive cells in the ventral neural tube or spinal cord (Fig. 10). Cx40, Cx43, and Cx45 immunoreactivity was also observed in the dorsal horn and in the dorsal root ganglia (data not shown). Confocal microscopic examination of immunostained sections revealed punctate staining that was associated with the motor neuron cytoplasm and membrane at these ages. The temporal and spatial expression pattern of each connexin protein was similar in the medial, dorsolateral, and ventrolateral motor columns. From P1 through adulthood, cytoplasmic, perinuclear, and membrane-associated Cx43 immunoreactivity was apparent in $>90 \%$ of motor neurons. The proportion of $\mathrm{Cx} 45$-positive motor neurons decreased from $\sim 90 \%$ at birth to $\sim 50 \%$ in adult spinal cord, whereas $\mathrm{Cx} 40$ immunoreactivity was detected in $<10 \%$ of motor neurons in adult spinal cord. Thus, for these three connexins, the spatial and temporal patterns of protein expression were similar to those observed for mRNA.

\section{DISCUSSION}

We used intracellular recordings to show that motor neurons are extensively electrically coupled at birth and that electrical cou- 


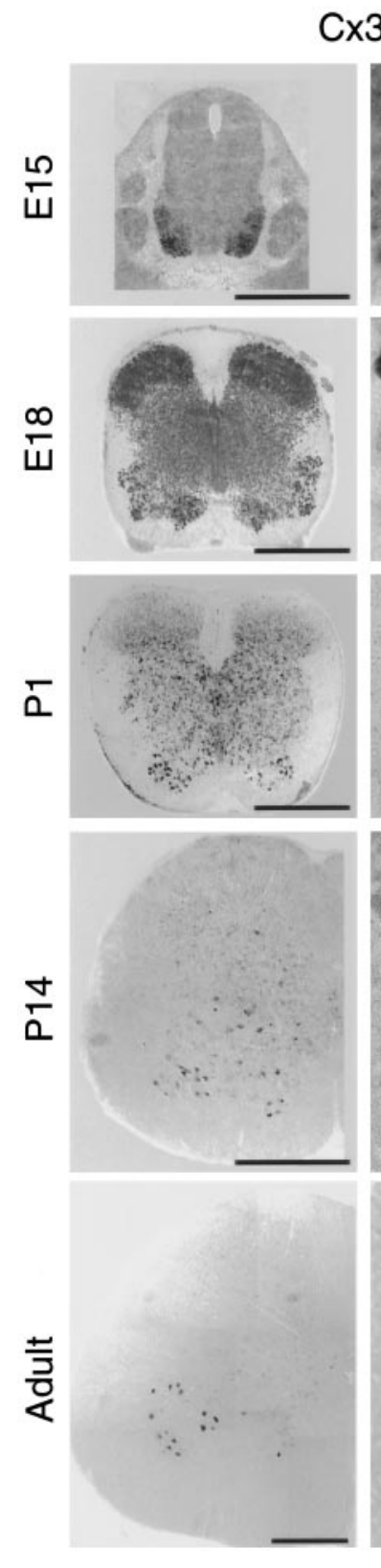

Cx36
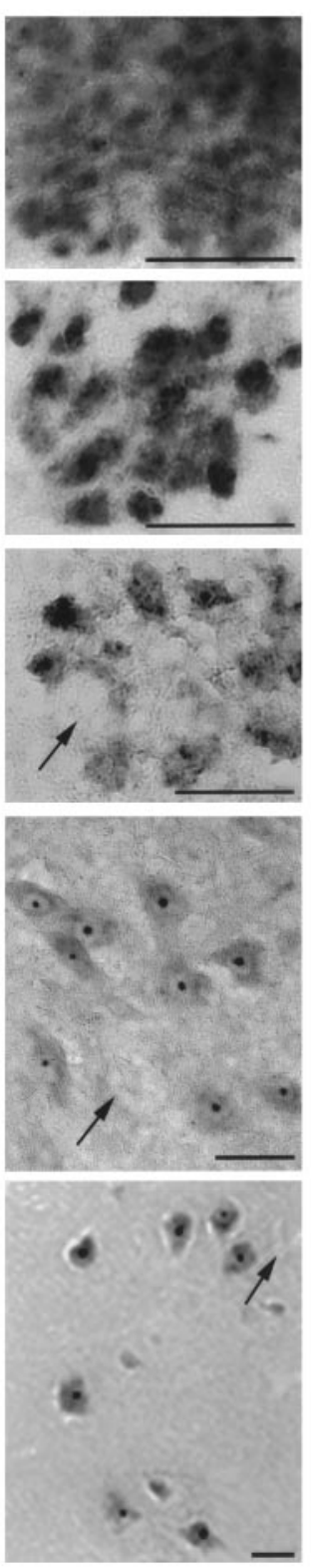

Cx37
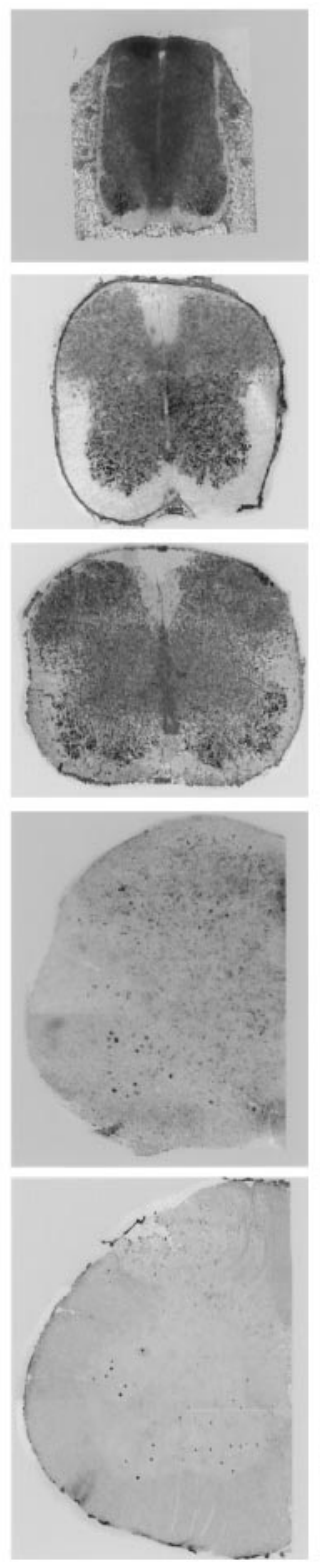

\section{Cx43}
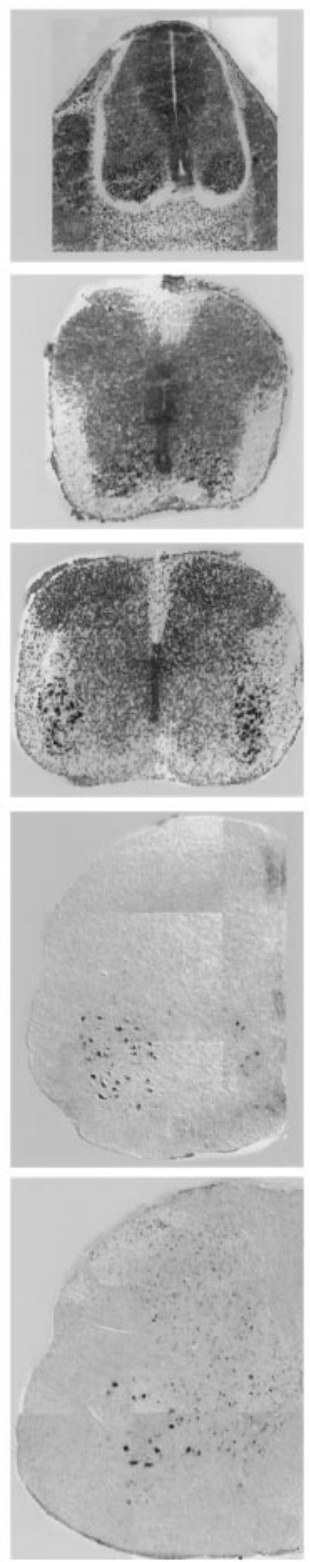

Figure 8. Cx36, Cx37, and $\mathrm{Cx} 43$ are expressed by developing and adult motor neurons. Shown are photographs of E15-adult lumbar spinal cord after in situ hybridization for Cx36 (left, left middle), $\mathrm{Cx} 37$ (right middle), and $\mathrm{Cx} 43$ (right) specific transcripts. Low- and high-power photomicrographs are shown for $\mathrm{Cx} 36$ hybridization signal; in left middle column, black arrows indicate examples of the relatively rare motor neurons that appeared negative for Cx36 mRNA. Similar observations were made with $\mathrm{Cx} 37$ and $\mathrm{Cx} 43$ probes. High-power images are representative fields from ventrolateral spinal cord where motor neurons are located. The temporal and spatial expression patterns of $\mathrm{Cx} 36, \mathrm{Cx} 37$, and $\mathrm{Cx} 43$ were similar, in that these connexins were expressed throughout the spinal cord at E15 and in the vast majority of motor neurons from E18 through P14 (see Table 2 for quantification). $\mathrm{Cx} 43$, and to a lesser extent Cx37, was expressed in dorsal root ganglia (E15, top row, lateral to spinal cord; data at other ages not shown). Cx36, Cx37, and Cx43 were also expressed in the dorsal horn. Surprisingly, expression was maintained in a substantial proportion of motor neurons in adult animals, despite the lack of functional gap junctional coupling after P3-P4 (also see Table 2). Scale bars: $500 \mu \mathrm{m}$ (low power Cx36, Cx37, and $\mathrm{Cx} 43$ ); $50 \mu \mathrm{m}$ (high power $\mathrm{Cx} 36$ ).

Table 2. Expression of connexin mRNA transcripts in rat lumbar spinal motor neurons

\begin{tabular}{|c|c|c|c|c|c|c|c|}
\hline & \multicolumn{3}{|c|}{ Expression in ventral spinal $\operatorname{cord}^{a}$} & \multicolumn{4}{|c|}{$\underline{\text { Percentage of positive motor neurons }}^{b}$} \\
\hline & E12 & E15 & E18 & $\mathrm{P} 1$ & $\mathrm{P} 7$ & $\mathrm{P} 14$ & Adult \\
\hline $\mathrm{Cx} 36$ & +++ & +++ & +++ & $100 \pm 0$ & $90 \pm 1$ & $92 \pm 1$ & $89 \pm 2$ \\
\hline $\mathrm{Cx} 37$ & +++ & +++ & +++ & $100 \pm 0$ & $93 \pm 2$ & $91 \pm 1$ & $91 \pm 1$ \\
\hline $\mathrm{Cx} 40$ & +++ & +++ & ++ & $91 \pm 4$ & $33 \pm 4$ & $17 \pm 2$ & $7 \pm 3$ \\
\hline $\mathrm{Cx} 43$ & +++ & +++ & +++ & $100 \pm 0$ & $95 \pm 1$ & $94 \pm 1$ & $93 \pm 1$ \\
\hline $\mathrm{Cx} 45$ & +++ & +++ & ++ & $83 \pm 1$ & $61 \pm 2$ & $58 \pm 3$ & $48 \pm 0$ \\
\hline $\mathrm{Cx} 32, \mathrm{Cx} 26$ & - & - & - & 0 & 0 & 0 & 0 \\
\hline
\end{tabular}

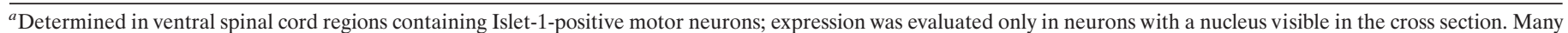
lumbar spinal cord sections from each of at least three animals were evaluated for each connexin.

${ }^{b}$ Values shown as mean \pm SEM. 


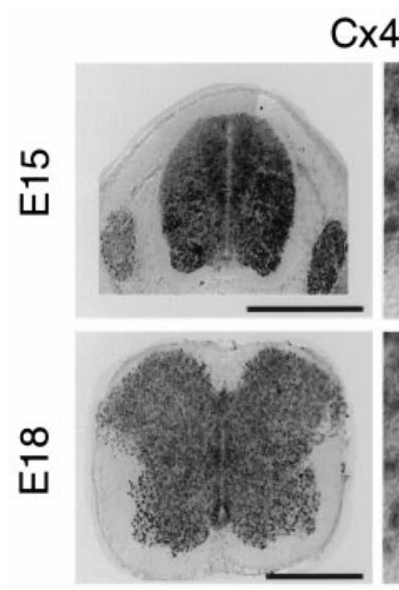

Figure 9. Motor neuron $\mathrm{Cx} 45$ and Cx40 expression decrease after birth. Shown are low- and high-power photographs of E15-adult lumbar spinal cord after in situ hybridization for Cx45-specific (left, left middle) and Cx40-specific (right middle, right) transcripts. High-power images are representative fields in ventrolateral spinal cord where motor neurons are located. Black arrows indicate the motor neurons that appeared negative for a particular connexin mRNA. At E15, Cx45 and $\mathrm{Cx} 40$ were expressed relatively uniformly throughout the spinal cord, and from E15 to E18, in most if not all motor neurons. Cx45 mRNA was also detected in dorsal root ganglia (left, E15 panel) and in scattered cells in the dorsal horn. After birth, however, the proportion of motor neurons expressing $\mathrm{Cx} 45 \mathrm{mRNA}$ decreased, with only $\sim 45 \%$ of motor neurons remaining positive in P14 and adult rat spinal cord. $\mathrm{Cx} 40$ was expressed throughout the spinal cord at E15-P1, including in ventral motor neurons and dorsal root ganglia (right middle, portions shown in E15 panel). Expression decreased after this time, with only $\sim 10 \%$ of motor neurons remaining positive at P14 or in adults. No differences were observed in the proportion of motor neurons positive for $\mathrm{Cx} 45$ or $\mathrm{Cx} 40$ transcripts in medial, dorsolateral, or ventrolateral motor columns at any of the ages examined. Scale bars: $500 \mu \mathrm{m}$ (low power $\mathrm{Cx}_{4} 4$ and $\mathrm{Cx} 40$ ); $50 \mu \mathrm{m}$ (high power $\mathrm{Cx} 45$ and $\mathrm{Cx} 40$ ).
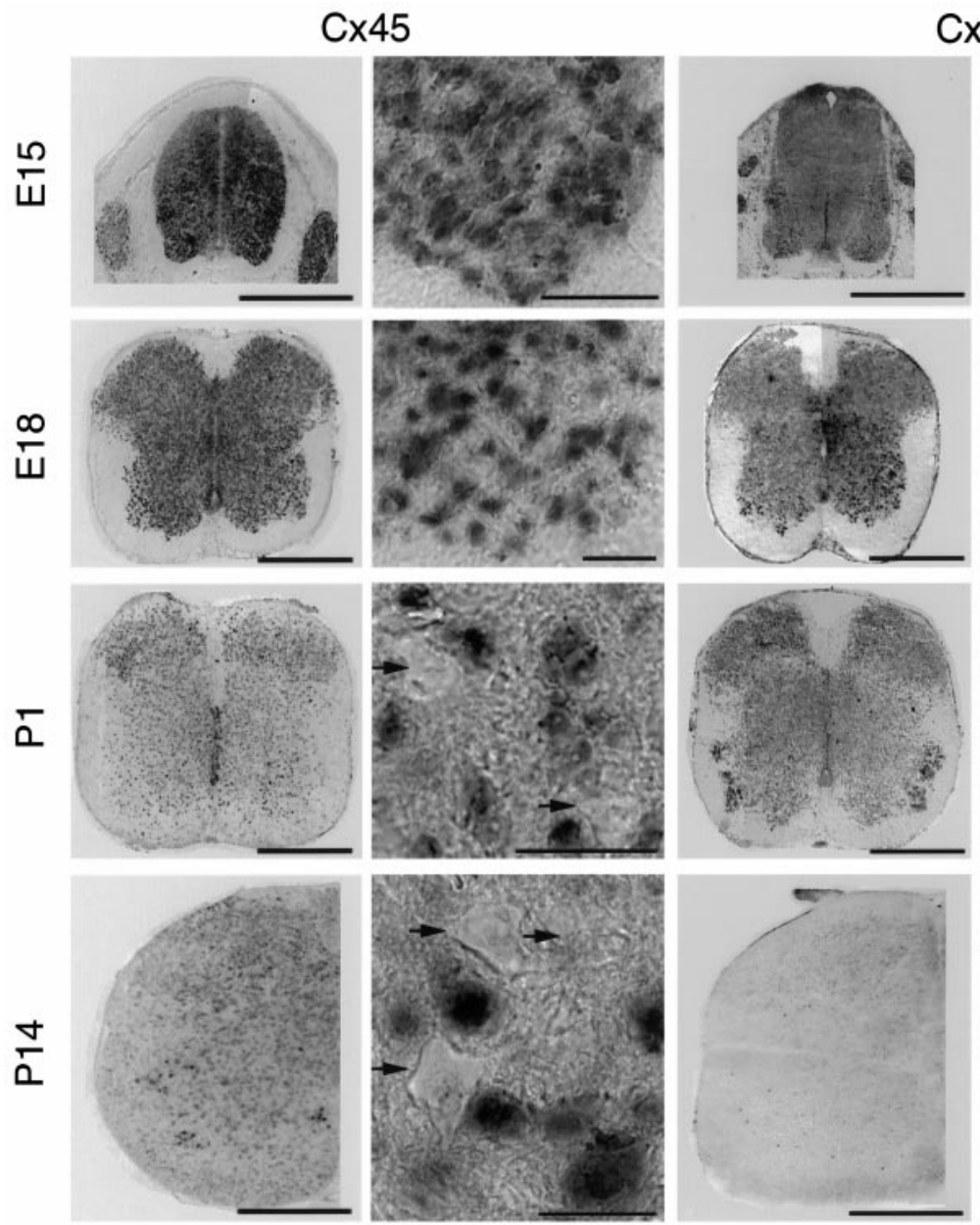

\section{$\mathrm{Cx} 40$}
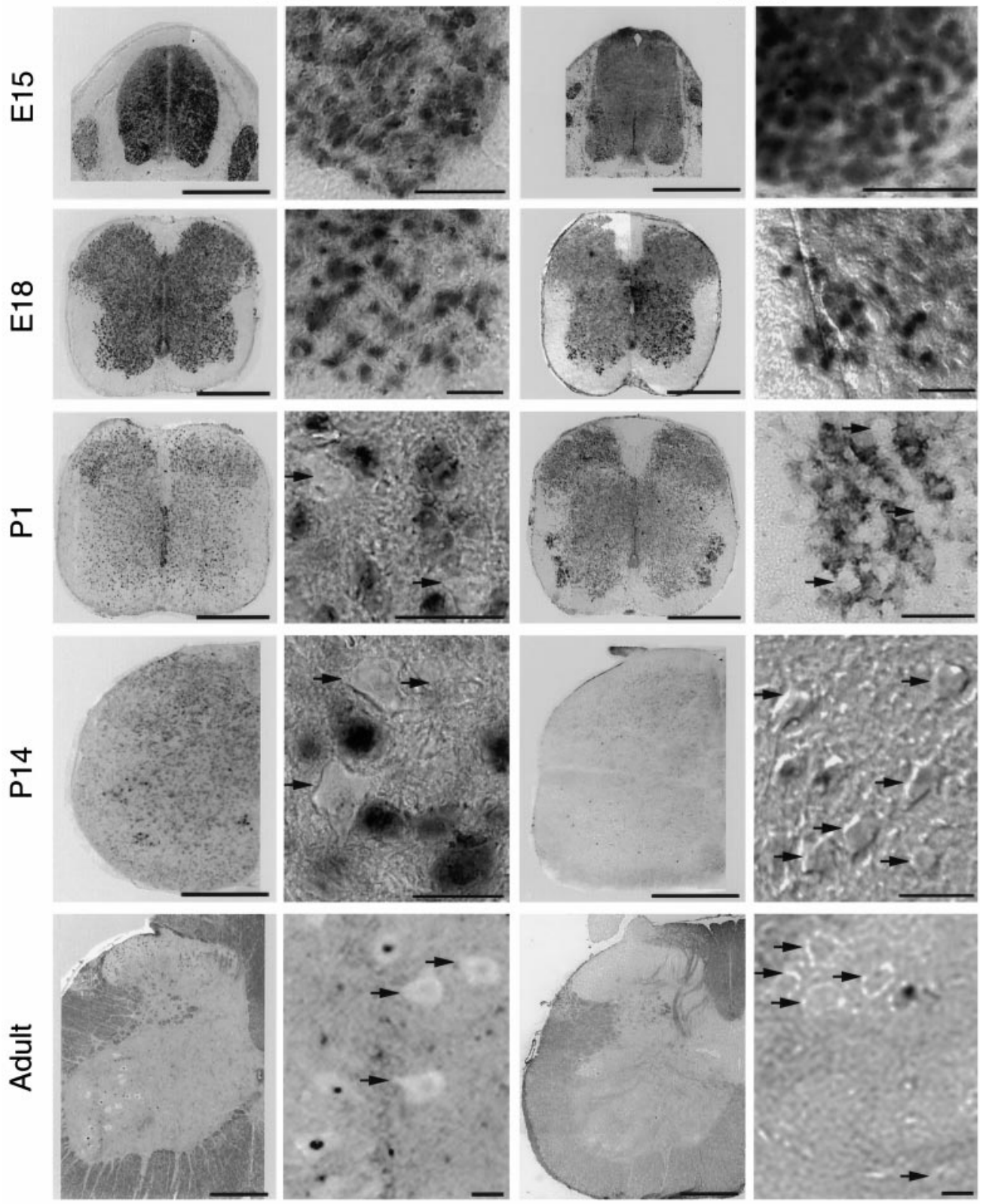

pling potentials were reversibly abolished by halothane, a widely used gap junction blocker. Iontophoretic injection of Neurobiotin, a low molecular weight compound that passes across gap junctions, into single motor neurons showed that at $\mathrm{P} 0-\mathrm{P} 2$, dyelabeled clusters contained on average six motor neurons, whereas by P7-P8, only single dye-labeled motor neurons were observed. Thus this work establishes the extent of dye and electrical coupling among motor neurons and a time course of their disappearance after birth. The spatial dimensions of clusters of dye-labeled motor neurons further suggests that, after birth at least, coupling is spatially restricted to small groups of motor neurons. We also report that motor neurons express five connexins: Cx36, Cx37, $\mathrm{Cx} 40, \mathrm{Cx} 43$, and $\mathrm{Cx} 45$. This repertoire is distinct from those previously described for cortical and other neurons (Dermietzel and Spray, 1993; Nadarajah et al., 1997; Nadarajah et al., 1996; Nadarajah and Parnavelas, 1999). Despite the observation that electrical and dye coupling are no longer present after the first

postnatal week, $\mathrm{Cx} 36, \mathrm{Cx} 37$, and $\mathrm{Cx} 43$ are expressed by a large proportion of adult motor neurons, whereas motor neuronal $\mathrm{Cx} 45$ and $\mathrm{Cx} 40$ expression decrease after birth.

Taken together, our results suggest two general mechanisms for the disappearance of electrical and dye coupling. The first is that the downregulation of $\mathrm{Cx} 40$ and/or $\mathrm{Cx} 45$ may lead to a decrease in functional gap junctions in motor neurons. This seems unlikely, given that this downregulation occurs more slowly than the disappearance of electrical and dye coupling, and that the connexins that continue to be expressed have been shown to form functional gap junctions in various cell types (Haubrich et al., 1996; Brink et al., 1997; Kumar, 1999; Li and Simard, 1999). The second is that gap junctional communication among motor neurons may be modulated by mechanisms that affect existing gap junction proteins, by modulating gap junction assembly, conductance, or open state. Our work provides a functional and molecular foundation for determining how gap junctional coupling may modulate motor 


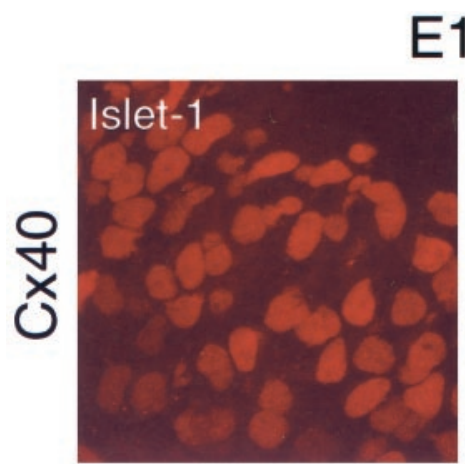

E15
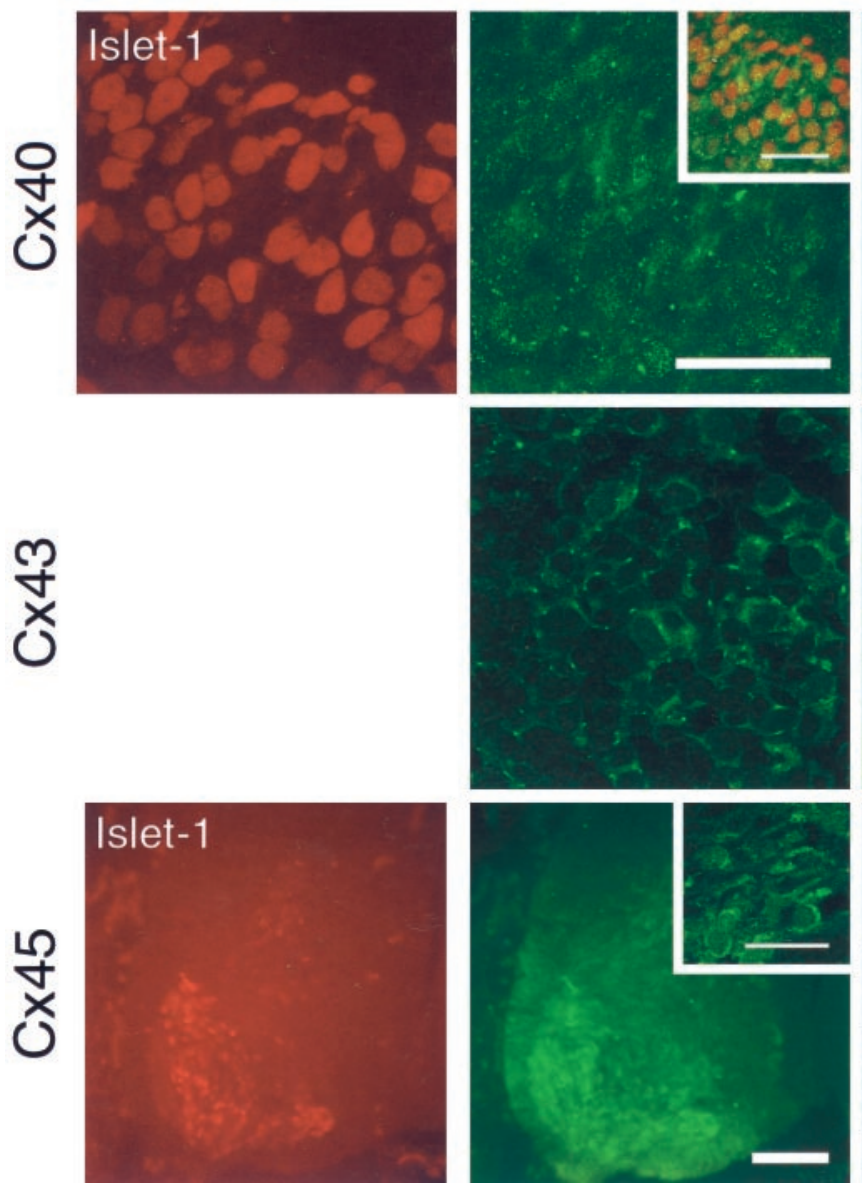
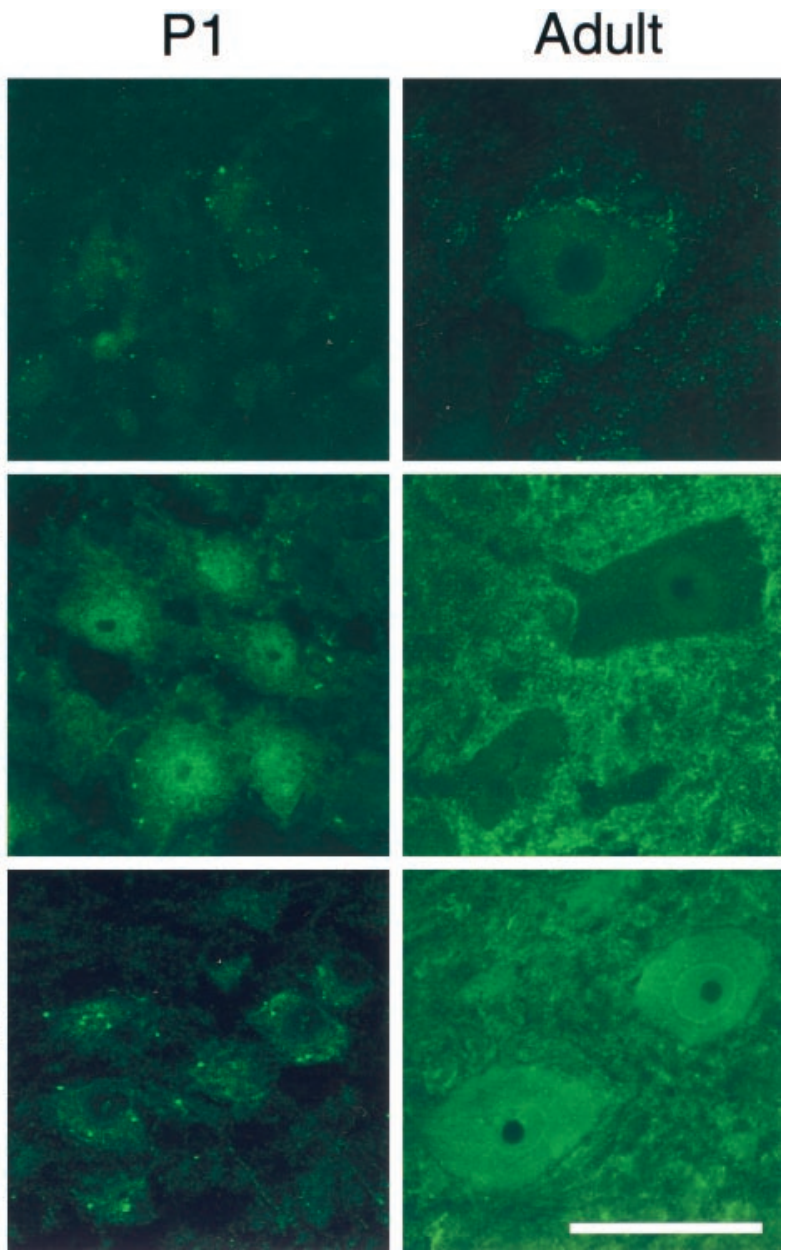

Figure 10. Connexin protein expression in developing and adult motor neurons. Confocal microscopic examination of immunostained sections revealed punctate membrane and diff use cytoplasmic staining for $\mathrm{Cx} 40, \mathrm{Cx} 43$, and $\mathrm{Cx} 45$. Shown in each panel is a single plane projection of a confocal stack of images. Top row, At E15, punctate Cx40 immunoreactivity was observed surrounding most Islet-1-positive cells (left panel) in the ventral spinal cord. The inset in second panel from left shows the overlay of Islet-1 and Cx40 immunostaining of this field. More diffuse staining within the cytoplasm was also observed. Scale bars, $100 \mu \mathrm{m}$. At P1, few motor neurons with punctate membrane staining and diff use cytoplasmic staining are observed. In adult spinal cord, few motor neurons are immunopositive for $\mathrm{Cx} 40$. Shown is one example of an adult motor neuron with characteristic punctate membrane as well as diffuse cytoplasmic staining; this was one of two positive motor neurons in the section. Middle row, At E15, punctate membrane Cx43 immunoreactivity and more diff use cytoplasmic staining were observed surrounding most motor neurons. Cx43 immunostaining was sensitive to fixation, and this precluded double-labeling with Islet-1. Scale is same as above. At P1, most motor neurons have both punctate membrane staining and diff use cytoplasmic staining. In adult spinal cord, dense punctate staining was observed in the neuropil surrounding motor neurons; this reflects Cx43 expression in glia (cf. Theriault et al., 1997). Punctate membrane as well as diffuse cytoplasmic staining are also observed in most motor neurons. Scale bar for P1 and adult panels: $50 \mu \mathrm{m}$. Bottom row, At E15, punctate membrane as well as diff use cytoplasmic Cx45 immunoreactivity was observed surrounding most Islet-1-positive cells (left panel) in the ventral spinal cord. Scale bar, $200 \mu \mathrm{m}$. The inset in second panel from left shows Cx45 staining in motor neurons at higher magnification. Scale bar, $50 \mu \mathrm{m}$. At P1, most motor neurons have both punctate membrane staining and diff use cytoplasmic staining. In adult spinal cord, about half of the motor neurons are immunopositive for $\mathrm{Cx} 45$. The temporal and spatial expression patterns of $\mathrm{Cx} 40$, $\mathrm{Cx} 43$, and $\mathrm{Cx} 45$ were similar in the medial, dorsolateral, and ventrolateral motor columns and similar to those observed for mRNA.

neuronal activity and affect synaptic connectivity within the spinal cord and with muscle targets.

\section{Neonatal motor neurons are electrically and dye coupled}

The results we present here are consistent with and extend previous work from neonatal rat spinal cord (Fulton et al., 1980; Walton and Navarette, 1991) and genioglossus motor neurons in rat brainstem (Mazza et al., 1992), which showed that electrical coupling potentials can be readily observed at birth but are only rarely observed after P6-P8. From this data and the more extensive characterization we present here, electrical coupling appears to be common among motor neurons in several different nuclei, and electrical coupling appears to generally disappear shortly after birth. Skeletal muscle fibers in the hindlimb are also transiently coupled by gap junctions, and this coupling also disappears within 1 or $2 \mathrm{~d}$ after birth (Schmalbruch, 1982; Balice-Gordon, unpublished results).

We directly compared the extent of electrical coupling with the extent of dye coupling by injecting single motor neurons with and without coupling potentials with Neurobiotin (Kita and Armstrong, 1991), which is known to readily pass through gap junction pores and thus can be used to characterize the extent of dye coupling (Stewart, 1978). From birth to P4, clusters of several neurons were dye-labeled after injection of a single motor neuron. By P7, only one or rarely two labeled neurons were detected, and at P8 only single labeled cells were observed. Postnatal loss of 
dye coupling has also been observed among genioglossus motor neurons in rat brainstem (Mazza et al., 1992). The absence of a correlation between the amplitude of electrical coupling potentials and the number of dye-labeled motor neurons may be attributable to an underestimate of electrical coupling caused by diminished detectability of electrical potentials because of electrotonic attenuation from dendrites to the soma, as well as to an underestimate of dye coupling, which is dependent on the amount of dye injected into one cell that successfully passes into coupled cells. However, our data show that developing spinal motor neurons are extensively dye-coupled at times when electrical coupling is present, and that electrical and dye coupling disappear with a similar time course.

The compact distribution of dye-labeled motor neurons, together with previous electrophysiological characterization (Walton and Navarette, 1991), suggests that dye and electrical coupling are present among neurons innervating the same muscle target and that dye coupling is not widely distributed across different motor pools. Because of the relatively rapid decrease in the extent of dye coupling observed after birth and the length of time it takes to retrogradely label motor neurons from hindlimb muscles (3-4 d; Q. Chang and R. Balice-Gordon, unpublished observations), it was not possible to retrogradely label complete muscle pools before intracellular recording and injection to address this possibility directly. Instead, we measured the dorsal-ventral, medial-lateral, and rostral-caudal dimensions of dye clusters (Fig. 5). The dimensions of even the largest cluster (19 cells, P0 spinal cord) are relatively small (Fig. 5), much less than the dimensions of individual motor pools reported previously (Swett et al., 1986; Hashizume et al., 1988; Westerga and Gramsbergen, 1992). Because motor neurons innervating different muscles are not extensively intermingled in the rat spinal cord (Swett et al., 1986; Hashizume et al., 1988; Westerga and Gramsbergen, 1992), the distribution of dye-labeled motor neurons implies that, after birth at least, dye coupling is present among motor neurons that innervate the same skeletal muscle. Using intracellular recording from identified motor neurons and selective stimulation of muscle nerves, Walton and Navarette (1991) analyzed the prevalence of "slow latency depolarizations," which by their resistance to superfusion with $\mathrm{Ca}^{2+}$-free, $\mathrm{Mg}^{2+}$-enriched saline were likely to be electrical coupling potentials. This work showed that lateral gastrocnemius, soleus, extensor digitorum longus, or tibialis anterior motor neurons are coupled to other motor neurons within their own pool, but no electrical potentials were observed between different pools. Together with the compact distribution of dyelabeled motor neuron clusters, the specificity indicated by these electrical stimulation experiments suggests that, after birth at least, electrical and dye coupling among motor neurons are relatively restricted, probably among motor neurons innervating the same skeletal muscle. It will be of interest to determine whether gap junctional coupling is less specific at earlier times in development, when decisions are being made about central and peripheral connectivity.

\section{Repertoire of connexins expressed by motor neurons}

The five connexins expressed by motor neurons, Cx36, Cx37, $\mathrm{Cx} 40, \mathrm{Cx} 43$, and $\mathrm{Cx} 45$, are distinct from those previously reported for other neurons (Nadarajah et al., 1996, 1997; Nadarajah and Parnavelas, 1999) or glia (Dermietzel and Spray, 1993; Bruzzone and Ressot, 1997). In neurons and other cell types, each of these has been shown to form functional homotypic and/or heterotypic gap junction channels that vary widely in permeability, conductance, gating, and other properties (Elfgang et al., 1995; Haubrich et al., 1996; Cao et al., 1998; Kumar, 1999). Thus in motor neurons there are many possible combinations of connexins that could form functional gap junctions, each with different functions, and these functions may be altered as expression levels change. Studies of mutant mice lacking one or more connexin(s) should allow these possibilities to be examined.

The relatively homogenous patterns of expression for Cx36, $\mathrm{Cx} 37$, and $\mathrm{Cx} 43$, together with the relatively homogeneous downregulation of $\mathrm{Cx} 45$ and $\mathrm{Cx} 40$ expression across motor columns, was particularly striking. We looked for, but did not observe, differences in the spatial and temporal aspects of mRNA and protein expression across motor columns and in rostral compared with caudal lumbar spinal segments. Thus the spatial restriction of coupling to small subsets of motor neurons within a pool that was observed after birth does not occur because of distinct spatial patterns of connexin expression among different motor neuron groups.

Given the fact that, around the time of birth, motor neuron cell bodies are displaced from one another as dendritic arbors are elaborated, it seems likely that the location of gap junctions is dendro-dendritic. Two recent ultrastructural studies report extensive gap junctions in spinal cord (Rash et al., 1996; van der Want et al., 1998). Rash et al. (1996) used confocal microscopy followed by freeze-fracture and scanning electron microscopic analysis to document mixed chemical and electrical synapses on neurons throughout the adult rat spinal cord, including on motor neurons. Van der Want et al. (1998) used retrograde labeling of adult rat soleus motor neurons with cholera toxin followed by transmission electron microscopy to demonstrate that gap junctions were present along proximal and distal motor neuron dendrites. In the context of the persistent connexin expression in adult spinal cord that we demonstrate here, it seems likely that structural gap junctions are constitutively present in motor neuron membranes, and that these are not functional after the first postnatal week, under normal circumstances at least. How the cellular localization and connexin composition of gap junctions may be altered during development will need to be resolved by immunoelectron microscopic analyses.

\section{Roles of gap junctional coupling in motor neuron development}

Transient gap junctional coupling among developing motor neurons might allow electrical and/or biochemical communication that could serve several roles. Because neural activity plays a critical role in the refinement of synaptic connections throughout the developing nervous system (for review, see Goodman and Shatz, 1993), a common pattern of activity among a group of developing neurons could help ensure that they receive similar synaptic inputs and make similar synaptic connections with common targets. Recent work from Milner and Landmesser (1999) suggests that electrical synapses may act in combination with chemical synapses to produce spontaneous bursting in chick lumbosacral motor neurons. By temporally correlating patterns of neuronal activity among coupled motor neurons, gap junctions might influence the specificity of their inputs during development or reinnervation.

Gap junctional coupling might also shape the synaptic connections of motor neurons with common muscle targets. Gap junctional coupling is present during the time that motor neurons extend axons and make synapses with skeletal muscle fibers, and temporally correlated motor neuron activity during early phases 
of synapse formation may allow synapses from several motor neurons to be established and transiently maintained with individual muscle fibers. As electrical coupling disappears, motor neuron activity may become progressively more asynchronous over time. This may be one of several mechanisms that underlie the synaptic competition, which results in the loss of multiple innervation and the establishment of the mature pattern of single innervation of muscle fibers (for review, see Thompson, 1985; Nguyen and Lichtman, 1996). The time course of electrical and dye coupling among lumbar spinal motor neuron established in the present work shows that gap junctional coupling disappears just before the loss of multiple innervation in distal limb muscles (Brown et al., 1976; Thompson et al., 1979; Balice-Gordon and Thompson, 1988). Previous work has suggested that synchronous activity (or inactivity) among the synaptic sites within a neuromuscular junction results in all synapses being maintained, whereas asynchronous activity leads to the permanent loss of the least active synapses (Balice-Gordon and Lichtman, 1994; Thompson, 1985) and may thus underlie the developmental transition from multiple to single innervation.

Although competition is modulated by the relative activity patterns of convergent inputs, little is known about how motor neuron activity patterns are shaped during development. The role of gap junctions can be evaluated by determining the relative firing of motor neurons to individual muscles in neonatal animals, and whether this firing is altered in animals in which gap junctional communication has been altered either pharmacologically or genetically. Preliminary results from electromyographic recordings of single motor unit activity suggest that motor unit firing is relatively temporally correlated around the time of birth, but temporal correlations are only rarely observed by the end of the second postnatal week (K. Personius and R. Balice-Gordon, unpublished results). It will be of interest to compare motor unit activity, the extent of electrical and dye coupling among motor neurons, and synaptic connectivity in mutant mice lacking one or more connexins.

Although gap junctions mediate electrical communication among some neurons, they also mediate biochemical communication, allowing the exchange of second messengers as well as other factors that may directly or indirectly modulate neuronal activity, as has been recently demonstrated in neocortex (Kandler and Katz, 1998). Biochemical coupling among sibling or small groups of neurons during neurogenesis might influence their subsequent differentiation as well as mediate signaling during the embryonic period of naturally occurring cell death. Coupling among embryonic motor neurons might help ensure that those neurons innervate a common target muscle and thus play a role in defining a motor pool. Biochemical coupling may also allow the dissemination of retrograde signals, derived from targets or from cells along axon pathways, among the innervating population of neurons that is essential for their survival. This may be important not only during development but also during reinnervation, when motor neurons rapidly reestablish connections with muscle fibers. Future work will be aimed at determining the relative roles of electrical and biochemical communication in shaping motor neuron connectivity within the spinal cord and with muscle targets.

\section{REFERENCES}

Baker R, Llinas R (1971) Electrotonic coupling between neurones in the rat mesencephalic nucleus. J Physiol (Lond) 212:45-63.

Balice-Gordon RJ, Lichtman JW (1994) Long-term synapse loss induced by focal blockade of postsynaptic receptors. Nature 372:519-524.
Balice-Gordon RJ, Thompson WJ (1988) Synaptic rearrangements and alterations in motor unit properties in neonatal rat extensor digitorum longus muscle. J Physiol (Lond) 398:191-210.

Bergoffen J, Scherer SS, Wang S, Scott M, Bone LJ, Paul DL, Chen K, Lensch MW, Chance PF, Fischbeck KH (1993) Connexin mutations in X-linked charcot-marie-tooth disease. Science 262:2039-2042.

Beyer EC, Paul DL, Goodenough DA (1987) Connexin43: a protein from rat heart homologous to a gap junction protein from liver. J Cell Biol 105:2621-2629.

Bittman K, Owens DF, Kriegstein AR, LoTurco JJ (1997) Cell coupling and uncoupling in the ventricular zone of developing neocortex. J Neurosci 17:7037-7044.

Brink PR, Cronin K, Banach K, Peterson E, Westphale EM, Seul KH, Ramanan SV, Beyer EC (1997) Evidence for heteromeric gap junction channels formed from rat connexin43 and human connexin37. Am J Physiol 273:C1386-1396.

Brown MC, Jansen JK, Van Essen D (1976) Polyneuronal innervation of skeletal muscle in new-born rats and its elimination during maturation. J Physiol (Lond) 261:387-422.

Bruzzone R, Ressot C (1997) Connexins, gap junctions and cell-cell signalling in the nervous system. Eur J Neurosci 9:1-6.

Burt JM, Spray DC (1989) Volatile anesthetics block intercellular communication between neonatal rat myocardial cells. Circ Res 65:829-837.

Camu W, Henderson CE (1992) Purification of embryonic rat motoneurons by panning on a monoclonal antibody to the low-affinity NGF receptor. J Neurosci Methods 44:59-70.

Camu W, Henderson CE (1994) Rapid putrification of embryonic rat motoneurons: an in vitro model for studying MND/ALS pathogenesis. J Neurol Sci 124:73-74.

Cao F, Eckert R, Elfgang C, Nitsche JM, Snyder SA, Hulser DF, Willecke $\mathrm{K}$, Nicholson BJ (1998) A quantitative analysis of connexin-specific permeability differences of gap junctions expressed in HeLa transfectants and Xenopus oocytes. J Cell Sci 111:31-43.

Chang Q, Balice-Gordon RJ (1997) Developmental regulation of connexin expression in motor neurons. Soc Neurosci Abstr 23:1677.

Chang Q, Gonzalez M, Pinter MJ, Balice-Gordon RJ (1998) Transient gap junction mediated coupling among developing motor neurons. Soc Neurosci Abstr 24:1040.

Condorelli DF, Parenti R, Spinella F, Salinaro AT, Belluardo N, Cardile V, Cicirata F (1998) Cloning of a new gap junction gene (Cx36) highly expressed in mammalian brain neurons. Eur J Neurosci 10:1202-1208.

Connors BW, Bernardo LS, Prince DA (1983) Coupling between neurons of the developing rat neocortex. J Neurosci 3:773-782.

Dermietzel R, Spray DC (1993) Gap junctions in the brain: where, what type, how many and why? Trends Neurosci 16:186-192.

Elfgang C, Eckert R, Lichtenberg-Frate H, Butterweck A, Traub O, Klein RA, Hulser DF, Willecke K (1995) Specific permeability and selective formation of gap junction channels in connexin-transfected HeLa cells. J Cell Biol 129:805-817.

Fulton BP, Miledi R, Takahashi T (1980) Electrical synapses between motoneurons in the spinal cord of the newborn rat. Proc R Soc Lond B Biol Sci 208:115-120.

Gabriels JE, Paul DL (1998) Connexin43 is highly localized to sites of disturbed flow in rat aortic endothelium but connexin 37 and connexin40 are more uniformly distributed. Circ Res 83:636-643.

Gogan P, Gueritaud JP, Horcholle-Bossavit G, Tyc-Dumont S (1974) Electrotonic coupling between motoneurones in the abducens nucleus of the cat. Exp Brain Res 21:139-154.

Goodman CS, Shatz CJ (1993) Developmental mechanisms that generate precise patterns of neuronal connectivity. Neuron 10:77-98.

Haefliger JA, Bruzzone R, Jenkins NA, Gilbert DJ, Copeland NG, Paul DL (1992) Four novel members of the connexin family of gap junction proteins. Molecular cloning, expression, and chromosome mapping. J Biol Chem 267:2057-2064.

Hashizume K, Kanda K, Burke RE (1988) Medial gastrocnemius motor nucleus in the rat: age-related changes in the number and size of motoneurons. J Comp Neurol 269:425-430.

Haubrich S, Schwarz HJ, Bukauskas F, Lichtenberg-Frate H, Traub O, Weingart R, Willecke K (1996) Incompatibility of connexin 40 and 43 hemichannels in gap junctions between mammalian cells is determined by intracellular domains. Mol Biol Cell 7:1995-2006.

Kandler K, Katz LC (1995) Neuronal coupling and uncoupling in the developing nervous system. Curr Opin Neurobiol 5:98-105. 
Kandler K, Katz LC (1998) Coordination of neuronal activity in developing visual cortex by gap junction-mediated biochemical communication. J Neurosci 18:1419-1427.

Kita H, Armstrong W (1991) A biotin-containing compound $\mathrm{N}$-(2aminoethyl)biotinamide for intracellular labeling and neuronal tracing studies: comparison with biocytin. J Neurosci Methods 37:141-150.

Kumar NM (1999) Molecular biology of the interactions between connexins. Novartis Found Symp 219:6-16.

Li J, Hertzberg EL, Nagy JI (1997) Connexin32 in oligodendrocytes and association with myelinated fibers in mouse and rat brain. J Comp Neurol 379:571-591.

Li X, Simard JM (1999) Multiple connexins form gap junction channels in rat basilar artery smooth muscle cells. Circ Res 84:1277-1284.

Llinas R (1985) Electronic transmission in the mammalian central nervous system. In: Gap junctions (Bennett MVL, ed), pp 337-353. Cold Spring Harbor, NY: Cold Spring Harbor Laboratory.

Llinas R, Sasaki K (1989) The functional organization of the olivocerebellar system as examined by multiple purkinje cell recordings. Eur J Neurosci 1:587-602.

MacVicar BA, Dudek FE (1981) Electrotonic coupling between pyramical cells: a direct demonstration in rat hippocampal slices. Science 213:782-784

Mazza E, Nunez-Abades PA, Spielmann JM, Cameron WE (1992) Anatomical and electrotonic coupling in developing genioglossal motoneurons of the rat. Brain Res 598:127-137.

Milner LD, Landmesser LT (1999) Cholinergic and GABAergic inputs drive patterned spontaneous motoneuron activity before target contact. J Neurosci 19:3007-3022.

Moreno AP, Rook MB, Fishman GI, Spray DC (1994) Gap junction channels: distinct voltage-sensitive and -insensitive conductance states. Biophys J 67:113-119.

Nadarajah B, Parnavelas JG (1999) Gap junction-mediated communication in the developing and adult cerebral cortex. Novartis Found Symp 219:157-170.

Nadarajah B, Thomaidou D, Evans WH, Parnavelas JG (1996) Gap junctions in the adult cerebral cortex: regional differences in their distribution and cellular expression of connexins. J Comp Neurol 376:326-342.

Nadarajah B, Jones AM, Evans WH, Parnavelas JG (1997) Differential expression of connexins during neocortical development and neuronal circuit formation. J Neurosci 17:3096-3111.

Nguyen QT, Lichtman JW (1996) Mechanism of synapse disassembly at the developing neuromuscular junction. Curr Opin Neurobiol 6:104-112.

Nicholson SM, Bruzzone R (1997) Gap junctions: getting the message through. Curr Biol 7:R340-R344.

Paul DL (1986) Molecular cloning of cDNA for rat liver gap junction protein. J Cell Biol 103:123-134.

Paul DL, Ebihara L, Takemoto LJ, Swenson KI, Goodenough DA (1991) Connexin46, a novel lens gap junction protein, induces voltage-gated currents in nonjunctional plasma membrane of Xenopus oocytes. J Cell Biol 115:1077-1089.

Peinado A, Yuste R, Katz LC (1993) Extensive dye coupling between rat neocortical neurons during the period of circuit formation. Neuron 10:103-114.

Rash JE, Dillman RK, Bilhartz BL, Duffy HS, Whalen LR, Yasumura T (1996) Mixed synapses discovered and mapped throughout mammalian spinal cord. Proc Natl Acad Sci USA 93:4235-4239.
Reaume AG, de Sousa PA, Kulkarni S, Langille BL, Zhu D, Davies TC, Juneja SC, Kidder GM, Rossant J (1995) Cardiac malformation in neonatal mice lacking connexin43. Science 267:1831-1834.

Rorig B, Sutor B (1996) Regulation of gap junction coupling in the developing neocortex. Mol Neurobiol 12:225-249.

Rozental R, Morales M, Mehler MF, Urban M, Kremer M, Dermietzel R, Kessler JA, Spray DC (1998) Changes in the properties of gap junctions during neuronal differentiation of hippocampal progenitor cells. J Neurosci 18:1753-1762.

Schmalbruch H (1982) Skeletal mucle fibers of newborn rats are coupled by gap junctions. Dev Biol 91:485-490.

Schwarz HJ, Chang YS, Hennemann H, Dahl E, Lalley PA, Willecke K (1992) Chromosomal assignments of mouse connexin genes, coding for gap junctional proteins, by somatic cell hybridization. Somat Cell Mol Genet 18:351-359.

Simon AM, Goodenough DA, Li E, Paul DL (1997) Female infertility in mice lacking connexin 37. Nature 385:525-529.

Simon AM, Goodenough DA, Paul DL (1998) Mice lacking connexin40 have cardiac conduction abnormalities characteristic of atrioventricular block and bundle branch block. Curr Biol 8:295-298.

Spray DC, White RL, Mazet F, Bennett MV (1985) Regulation of gap junctional conductance. Am J Physiol 248:H753-764.

Steinberg TH, Civitelli R, Geist ST, Robertson AJ, Hick E, Veenstra RD, Wang HZ, Warlow PM, Westphale EM, Laing JG (1994) Connexin43 and connexin 45 form gap junctions with different molecular permeabilities in osteoblastic cells. EMBO J 13:744-750.

Stewart WW (1978) Functional connections between cells as revealed by dye-coupling with a highly fluorescent naphthalimide tracer. Cell 14:741-759.

Swett JE, Wikholm RP, Blanks RH, Swett AL, Conley LC (1986) Motoneurons of the rat sciatic nerve. Exp Neurol 93:227-252.

Theriault E, Frankenstein UN, Hertzberg EL, Nagy JI (1997) Connexin43 and astrocytic gap junctions in the rat spinal cord after acute compression injury. J Comp Neurol 382:199-214.

Thompson W, Kuffler DP, Jansen JKS (1979) The effect of prolonged, reversible block of nerve impulses on the elimination of polyneuronal innervation of new-born rat skeletal muscle fibers. Neuroscience $4: 271-281$.

Thompson WJ (1985) Activity and synapse elimination at the neuromuscular junction. Cell Mol Neurobiol 5:167-182.

Tsuchida T, Ensini M, Morton SB, Baldassare M, Edlund T, Jessell TM, Pfaff SL (1994) Topographic organization of embryonic motor neurons defined by expression of LIM homeobox genes. Cell 79:957-970.

van der Want JJ, Gramsbergen A, Ijkema-Paassen J, de Weerd H, Liem RS (1998) Dendro-dendritic connections between motoneurons in the rat spinal cord: an electron microscopic investigation. Brain Res 779:342-345.

Verselis V, White RL, Spray DC, Bennett MV (1986) Gap junctional conductance and permeability are linearly related. Science 234:461-464.

Walton KD, Navarrete R (1991) Postnatal changes in motoneurone electrotonic coupling studied in the in vitro rat lumbar spinal cord. J Physiol 433:283-305.

Westerga J, Gramsbergen A (1992) Structural changes of the soleus and the tibialis anterior motoneuron pool during development in the rat. J Comp Neurol 319:406-416.

Yuste R, Peinado A, Katz LC (1992) Neuronal domains in developing neocortex. Science 257:665-669.

Zhang JT, Nicholson BJ (1989) Sequence and tissue distribution of a second protein of hepatic gap junctions, $\mathrm{Cx} 26$, as deduced from its cDNA. J Cell Biol 109:3391-3401.

Ziskind-Conhaim L (1988) Physiological and morphological changes in developing peripheral nerves of rat embryos. Dev Brain Res 42:15-28. 